(C) А.В. Леонов, В.М. Пищальник, В.И. Петухов, О.В. Чичерина, 2018,

Океанологические исследования, 2018, Том 46, № 2, С. 112-144

УДК 574.5(261.24)+574.5.001.57+551.463.8 DOI: 10.29006/1564-2291.JOR-2018.46(2).10

\title{
TRANSFORMATIONS OF NUTRIENTS IN THE NORTHEASTERN WATERS OF THE SAKHALIN SHELF: AN ANALYSIS OF MATHEMATICAL MODELING RESULTS
}

\author{
A.V. Leonov', V.M. Pishchal'nik' ${ }^{2}$, V.I. Petukhov ${ }^{3}$, O.V. Chicherina1 \\ ${ }^{1}$ Shirshov Institute of Oceanology, Rusian Academy of Sciences \\ 36, Nachimovskij Prospekt, Moscow, 117997, Russia \\ ${ }^{2}$ Sakhalin State University, 290, Lenin Street, Uzhno-Sakhalinsk, 693008, Russia \\ ${ }^{3}$ Far Eastern Federation University, 8, Sukhanova St., Vladivostok, 690091, Russia \\ e-mail:leonov@ocean.ru
}

Submitted 01.06.2018, accepted 18.09.2018

\begin{abstract}
Transformations of nutrients in marine environments of the Northeastern part of Sakhalin Shelf were studied in Regions 1-4. Three electronic devices were used for the analysis of the oceanographic information:

1. The GIS «Sakhalin Shelf» (to obtain data on the state of thermohaline parameters of sea waters).

2. The oceanic dynamic model of the Bergen University (to estimate the rates of water mass transport across boundaries of regions).

3. The hydroecological CNPSi-model (to calculate the chemical and biological characteristics and estimate qualitatively the features of the marine environment biohydrochemistry in various regions of Northeastern part of Sakhalin Shelf.

In this study the seasonal dynamics of the concentrations of organic and mineral substances of biogenic elements ( $\mathrm{N}$ and $\mathrm{P}$ ), and organism biomasses (heterotrophic bacteria, three groups of phytoplankton, and two groups of zooplankton are presented, which were reproduced on the basis of the long-term monthly values of the marine environment parameters (temperature, light intensity, transparency of water environment, biogenic load, water exchange parameters). Indicated organisms are involved in the substance transformations and providing their turnover in the water environment. An analysis of the changes in the nutrient concentrations allowed us to characterize the conditions during a year for the explanations of biomass organism development and change in values of their activity parameters (on the base of specific biomass growth rates and bioproductions).
\end{abstract}

Keywords: models for analysis of oceanological data; concentrations of nutrients; organism biomasses of lower trophic links - heterotrophic bacteria, three main groups of phytoplankton; herbivorous and predatory; specific growth rate, biomass turnover time, bioproduction

\section{Introduction}

Presently, the main tasks of biohydrochemical research, solved with the help of mathematical modeling, are connected with the study of the dynamics of nutrient substances (BS), their chemical and biological transformation in the aquatic environment and in sediments, the rates of chemical and biological processes, the circulation of BS in natural waters, conditions the formation of bioproductivity of water bodies, the balance of organogenic compounds, the study of metabolic processes at the interfaces of river 
runoff-sea, water-atmosphere and water-bottom. In the aquatic environment, physical, chemical and biological processes associated with the transformation and chemicalbiological transformation of BS of natural and anthropogenic origin are carried out. When studying the composition of the components of the aquatic environment, these processes should be considered not in isolation, but in close interconnection. Therefore, the modern methodology for studying the composition of the components of natural waters is based on the principles of system analysis, combining the results of research on the basic natural disciplines (chemistry, physics, biology, geography, geology), as well as related sciences (biohydrochemistry, geochemistry, biophysics, micro- and hydrobiology).

The degree of complexity of model development is reflected in the received ideas about the subject, the study of certain issues of the composition of the components of natural waters, the availability of information on individual disciplines that study the state of water resources. The methodology of model development is based on a combination of deterministic description of chemical, biological and physical processes developing in the aquatic environment. The studied water bodies are subdivided into regions, each of which is studied separately. As a result, quantitative information on the changes in time of chemical and biological characteristics is obtained depending on the impact on the ecosystem of the water body of the habitat factors - temperature (Tw), light intensity, water transparency, water regime, nutrient load (Leonov, 1999).

The research methodology in these studies is based on the application of third instruments for the analysis of oceanological data:

1. The GIS «Sakhalin Shelf» (Pishchal'nik, Bobkov, 2000) (for processing thermohaline observational data).

2. Hydrodynamic ocean model of the Bergen University (BOM) (Berntsen, 2004) (for calculations on thermohaline data of velocities and directions of currents and rates of water exchange).

3. The hydroecological CNPSi-model of transformation / turnover of BS (compounds of C, N, P, Si (Leonov, 2012) for calculating the dynamics of BS and biomass of organisms involved in their transformation). Instruments (1)-(3) are simultaneously used since 2007 to study the features of hydrodynamics of waters and biohydrochemistry of marine environments (Leonov et. al., 2010 a; b; 2016).

Calculations of currents for the Eastern Sakhalin Self were performed with the help of oceanic BOM model (Berntsen, 2004) for each month on the base of thermohaline parameter values (data accumulated in the GIS «Sakhalin Shelf» includes observations for 1948-1995 during the ice-free period at standard oceanographic stations in the offshore area of Sakhalin: for $T_{\mathrm{w}}-18359$, water salinity -13480 , values of water $\mathrm{pH}-4367$, content of $\mathrm{O}_{2}-6176$, of $\mathrm{NO}_{2}-1457$, of $\mathrm{P}-1492$, and of Si-1650 (Pishchal'nik, Bobkov, 2000)).

The following features of the dynamics of marine currents on the Northeastern Sakhalin Shelf (NESS) are revealed:

- the restructuring of the water circulation scheme in the surface 100-m layer of shelf in the annual cycle occurs twice: in May-June and September-October; 
- the calculated velocities of marine currents under ice in the area of NESS fluctuate from 4 to $7 \mathrm{~cm} / \mathrm{s}$, and the maximum velocities of water movement on the surface are observed in November $(22.5 \mathrm{~cm} / \mathrm{s})$ (Pischal'nik et al., 2014).

Calculated current rates are coincided with measured in observations [Luchin et al., 1998].

The hydroecological CNPSi-model (simulation model of the transformation of C, N, P, Si -substances (Leonov, 2012)) calculates:

- instantaneous rates of changes in substance concentrations over all the considered transformation patways;

- instantaneous concentrations of the state variables of the aquatic environment and bottom sediments in the studied ecosystem;

- turnover times of each chemical and biologocal state variables and the rates of biomass productions;

- substance fluxes through internal and external transformation patways;

- complete balances of C, N, P, Si - substances for regions of the studied water area.

Calculations of the change in the substance concentrations were carried out for two years to assess the values of biohydrochemical parameters at the end of the first year corresponding to the average long-term environmental parameters. These values are taken as an initial concentrations, corresponding to the long-term environmental conditions, for the second year of calculations, to represent the seasonal dynamics of substance concentrations, biomass of organisms, an internal / external substance fluxes for the biohydrochemical characterizing of marine ecosystem behaviour depending on environmental conditions and antrophogenic influence (Leonov, 2012).

\section{The short information for the hydroecological CNPSi-model}

The hydroecological CNPSi-model (Leonov, 2012) is the formalized description of the interrelated biohydrochemical cycles of $\mathrm{N}$ - and P-substances, the most important processes of transformation of dissolved organic $\mathrm{C}$ (DOC), $\mathrm{Si}, \mathrm{O}_{2}$, and $\mathrm{N}_{2}$ in a twolayered water system. The model is intended to study the effect on the marine ecosystem of the main natural and anthropogenic factors $\left(T_{w}\right.$, light intensity, transparency of the water environment, biogenic load, water exchange). Month variations of these factors regulate the rates of the $\mathrm{BS}$ concentration changes, as well as the biomass of biological compartments the marine environment. The CNPSi-model calculates the intra-annual variations in the concentrations of $\mathrm{DOC}$ and $\mathrm{O}_{2}$, detrital fractions of $\mathrm{P}(\mathrm{PD}), \mathrm{N}(\mathrm{ND})$, and $\mathrm{Si}(\mathrm{SiD})$, dissolved organic fractions of $\mathrm{P}$ (DOP), $\mathrm{N}(\mathrm{DON})$ and $\mathrm{Si}$ (DOSi), dissolved mineral forms of $\mathrm{P}$ (DIP), $\mathrm{Si}$ (DISi), and $\mathrm{N}$ (ammonium, $\mathrm{NH}_{4}$, nitrites, $\mathrm{NO}_{2}$, and nitrates, $\mathrm{NO}_{3}$ ). Changes in the concentrations of BS are determined by the activity of organisms of the lower trophic chains - heterotrophic bacteria $(B 1)$, three dominant phytoplankton groups $(F 1, F 2, F 3)$, and two zooplankton groups - herbivorous $(Z 1)$ and predatory $(Z 2)$ (Leonov, 2012).

The structure of CNPSi-model most fully meets the requirements for applied models for studying the conditions in the formation of water quality and the state of 
marine ecosystems. The peculiarity of the model is the explicit role of organisms in the mathematical description: in the biochemical oxidation of natural components, BS, and organic matter $(\mathrm{OM})$ of the marine environment and pollutants, as well as in the cycle and regeneration of mineral compounds of biogenic elements $(\mathrm{C}, \mathrm{N}, \mathrm{P}, \mathrm{Si})$. The structure of the CNPSi-model equations was considered in (Leonov, 2012).

The program of the model is written in REM-FORTRAN. Visualization of simulation results (data of calculations) is carried out using the built-in CNPSi-model of the display system, adapted for WINDOWS-XP (Leonov et al., 2012).

\section{Zoning of the water area of the Northeastern Sakhalin shelf}

The entire water area of the NESS is divided into Regions 1-4 (Fig. 1). The morphometric parameters of these regions are presented in Table 1. Analysis of the oceanological parameters of the marine environment in the waters of the NESS (Fig. 1) made it possible to distinguish for Regions 1-4 their mean depths $(640,1520,300$ and $730 \mathrm{~m}$, respectively). The smallest values of the water area and the water volume are in Region 2 (15 thousand $\mathrm{km}^{2}$ ) and in Region 3 (10.5 thousand $\mathrm{km}^{3}$ ), respectively. The values of water area and water volume are greatest in the Region 1:48 thousand $\mathrm{km}^{2}$ and 30.7 thousand $\mathrm{km}^{3}$ respectively (Table 1 ).

The next information were used as initial data for the calculations on the CNPSimodel: the morphometric parameters of the selected Regions 1-4 (mean depths, areas and water volumes), concentrations of BS in the tributaries and adjacent water areas, the long-term values of the marine environment state (mean monthly values of water temperature $\left(T_{w}\right)$, light intensity, and the transparency of waters, as well as the values of water exchange (flow rates) between Regions 1-4 and open water areas of the Sea of Okhotsk. The water exchange parameters were calculated on the basis of the current indicators for the water areas of the NESS on the base of the oceanic model of the Bergen University $(\mathrm{BOM})$ on the long-term observations for $T_{w}$ and salinity $\left(S_{w}\right)$ of the sea waters of the NESS area.

The methodology for preparing the initial data for calculations on the CNPSimodel was used earlier in the study by modeling the transformation conditions for BS and spatial transport of substances in the marine waters washing the shores of Sakhalin Island (Pishchal'nik, Leonov, 2003; Leonov, Pishchal'nik, 2005 a, b; Leonov et al., 2010 a, b; Pishchal'nik, et al., 2011).

Table 1. Morphometric characteristics of the Regions 1-4 of NESS

\begin{tabular}{|l|c|c|c|c|}
\hline Characteristic dimension & 1 & 2 & 3 & 4 \\
\hline Mean depth, $\mathrm{m}$ & 640 & 1520 & 300 & 730 \\
\hline Water area, thous. $\mathrm{km}^{2}$ & 48 & 15 & 35 & 18.7 \\
\hline Water volume, thous. $\mathrm{km}^{3}$ & 30.7 & 22.8 & 10.5 & 13.7 \\
\hline
\end{tabular}




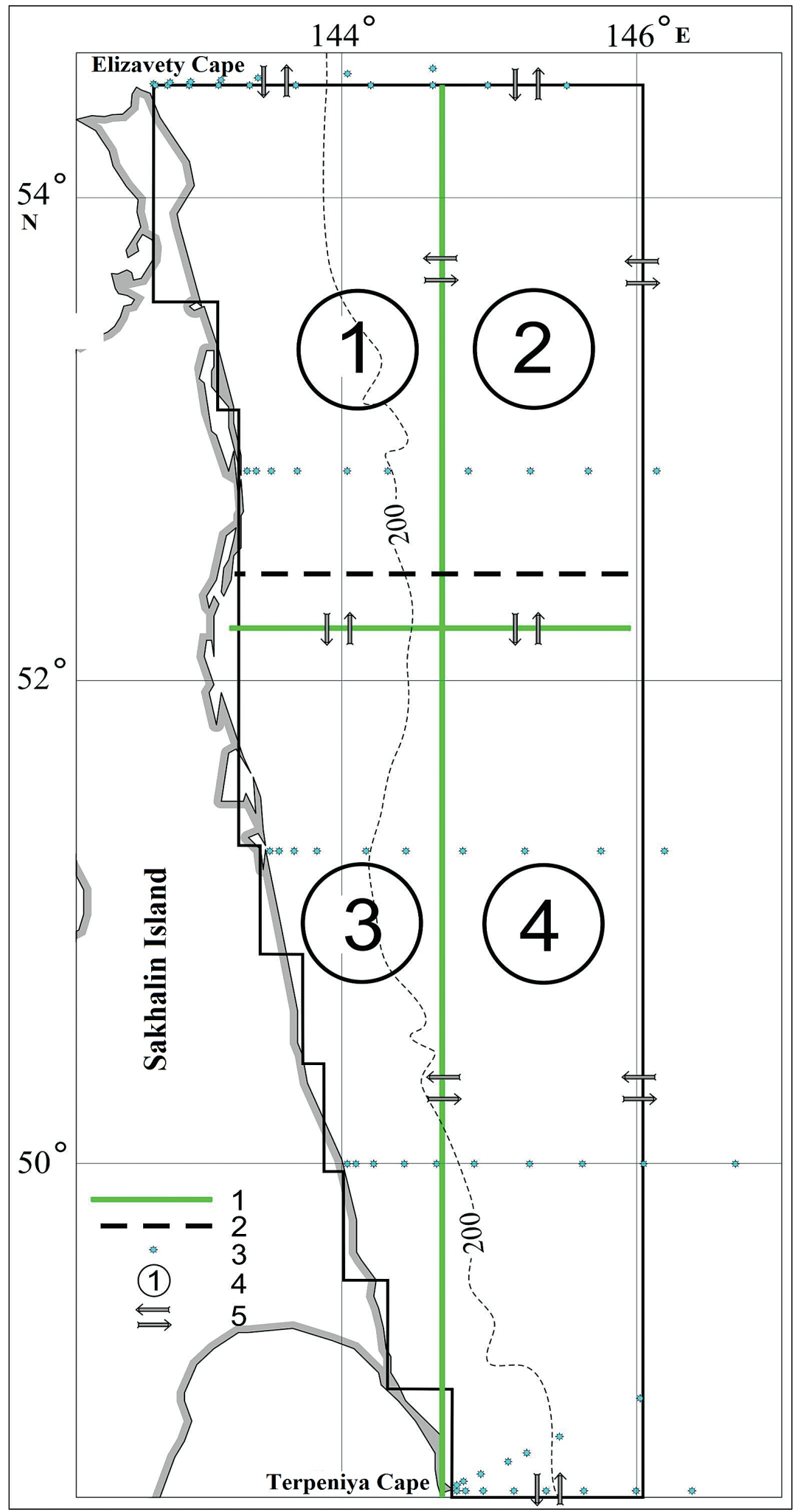

Fig. 1. Map-scheme of the water area of NESS (1 - the boundaries of Regions $1-4 ; 2$ - the standard cross-section for $52^{\circ} 30^{\circ} \mathrm{N} ; 3$ - the location of standard stations in waters of NESS; 4 - numbers of regions; 5 - directions of water transfer through boundaries between regions and with open-waters of the Sea of Okhotsk 
Table 2. Long-term values of marine environmental characteristics by month for Regions 1-4 of NESS (dash means that the layer was not chosen; here and in Table 3, the numbers above and below the line are for the top and bottom layers, respectively)

\begin{tabular}{|c|c|c|c|c|c|c|c|c|c|c|c|c|}
\hline Region & I & II & III & IV & $\mathrm{V}$ & VI & VII & VIII & IX & $\mathrm{X}$ & XI & XII \\
\hline \multicolumn{13}{|c|}{ Depth of vertical mixing of water $(\mathrm{XI}-\mathrm{V})$ and termocline position $(\mathrm{VI}-\mathrm{X}), \mathrm{m}$} \\
\hline $1-4$ & 150 & 150 & 150 & 150 & 150 & 20 & 30 & 40 & 50 & 60 & 75 & 100 \\
\hline \multicolumn{13}{|c|}{ Water temperature, ${ }^{\circ} \mathrm{C}$} \\
\hline \multirow{2}{*}{1} & -0.8 & -1.2 & -1.3 & -1.4 & -1.1 & 1.7 & 4.6 & 5.4 & 6.2 & 3.7 & 1.1 & 0.0 \\
\hline & 1.5 & 1.0 & 1.0 & 1.0 & 1.4 & -0.3 & 0.0 & 0.3 & 0.5 & 0.6 & 0.8 & 0.8 \\
\hline \multirow{2}{*}{2} & -0.6 & -1.0 & -1.2 & -1.2 & -0.9 & 3.1 & 6.5 & 6.7 & 6.9 & 4.1 & 1.2 & 0.1 \\
\hline & 1.4 & 1.4 & 1.4 & 1.4 & 1.4 & 0.8 & 1.0 & 1.0 & 1.0 & 1.2 & 1.3 & 1.3 \\
\hline \multirow{2}{*}{3} & -0.6 & -1.2 & -1.4 & -1.4 & -1.1 & 2.4 & 4.8 & 5.5 & 6.1 & 4.0 & 1.9 & 0.2 \\
\hline & 0.2 & -0.2 & -0.6 & -0.7 & $-0,6$ & -0.7 & -0.3 & -0.1 & 0.2 & 0.4 & 0.5 & 0.2 \\
\hline \multirow{2}{*}{4} & -0.4 & -1.1 & -1.3 & -1.3 & $-0,9$ & 3.0 & 5.7 & 6.0 & 6.3 & 4.3 & 2.0 & 0.3 \\
\hline & 0.8 & 0.6 & 0.5 & 0.5 & 0.5 & 0.1 & 0.2 & 0.3 & 0.4 & 0.6 & 0.8 & 0.8 \\
\hline \multicolumn{13}{|c|}{ Light intensiry, cal/(sm² day) } \\
\hline $1-4$ & 90.3 & 114.2 & 167.8 & 213.4 & 219.4 & 240.0 & 219.4 & 206.5 & 200.0 & 128.8 & 120.0 & 90.3 \\
\hline \multicolumn{13}{|c|}{ Photoperiod, dimensionless } \\
\hline $1-4$ & 0.32 & 0.39 & 0.48 & 0.60 & 0.66 & 0.71 & 0.69 & 0.62 & 0.54 & 0.48 & 0.34 & 0.32 \\
\hline \multicolumn{13}{|c|}{ Precipitation, $\mathrm{km}^{3}$} \\
\hline $1-2$ & 1.113 & 0.894 & 0.978 & 1.492 & 1.956 & 1.834 & 2.760 & 3.191 & 3.583 & 2.702 & 1.692 & 1.608 \\
\hline $3-4$ & 1.575 & 1.143 & 1.134 & 1.253 & 1.609 & 1.524 & 2.269 & 2.379 & 2.642 & 2.261 & 2.159 & 2.057 \\
\hline \multicolumn{13}{|c|}{ Secchi depth, m } \\
\hline 1 & 1 & 1 & 1 & $1(0)$ & 3 & 6 & 7 & 7 & 8 & 8 & 9 & 8 \\
\hline 2 & 2 & 3 & 1 & 1 & 5 & 8 & 8 & 7 & 8 & 10 & 11 & 12 \\
\hline 3 & 1 & 2 & 1 & $1(0)$ & 6 & 7 & 8 & 7 & 8 & 8 & 9 & 10 \\
\hline 4 & 1 & 1 & 1 & 1 & 8 & 7 & 8 & 7 & 8 & 10 & 10 & 12 \\
\hline
\end{tabular}

The main seasonal features in changes of thermohaline parameters in the Regions 1-4 of the NESS are singled out. The analysis of the data on the vertical distribution of $T_{\mathrm{w}}$ in the waters of the NESS, performed with the help of GIS «Sakhalin Shelf», revealed a subdivision of the water column into two layers during a year [Pishchal'nik et al., 2014]: in the cold period, this is associated with the development of winter vertical water circulation processes, and in warm weather - with warming up surface layer. Accordingly, in Regions 1-4 during the cold period (January-May), the thickness of the surface layer with negative values of mean $T_{\mathrm{w}}\left(-0.4-1.4^{\circ} \mathrm{C}\right)$ reaches $150 \mathrm{~m}$. It should be noted that the mean $T_{\mathrm{w}}$ of the subsurface layer during a year in Regions 2 and 4 remain low, but retain positive values (respectively $0.8-1.4$ and $0.1-0.8^{\circ} \mathrm{C}$ ); in the Region 3 , the 
subsurface waters with the negative $T_{\mathrm{w}}\left(-0.1 \ldots-0.7^{\circ} \mathrm{C}\right)$ is noted in February-August, and in the remaining months, the average $T_{\mathrm{w}}$ varies here within $0.2-0.5^{\circ} \mathrm{C}$. In Region 1 in the subsurface layer, the average $T_{\mathrm{w}}$ has the lowest values in the period of June-August ( -0.3 , 0.0 , and $0.3^{\circ} \mathrm{C}$, respectively), in the remaining months of a year, the average values of $T_{\mathrm{w}}$ vary within the range of $0.5-1.5^{\circ} \mathrm{C}$ (Table 2 ).

In waters of Regions $1-4$, the highest average values of $T_{w}$ in the surface layer were recorded in September $\left(6.2,6.9,6.1\right.$, and $6.3^{\circ} \mathrm{C}$, respectively). The maximum warming of surface waters is recorded in open waters (Region 2), and the minimum - in the coastal Region 3 (as a result of the clearly pronounced upwelling of waters). In the spring-summer period, water heating does not extend to depths $>30 \mathrm{~m}$, and autumn mixing of water is accompanied by a decrease in the values of mean $T_{w}$ of the upper quasihomogeneous layer (in October to $3.7-4.3^{\circ} \mathrm{C}$, in November to $1.1-2.0^{\circ} \mathrm{C}$, in December to $0.0-0.3^{\circ} \mathrm{C}$ ) and an increase in the thickness of this layer (up to 60, 75, and $100 \mathrm{~m}$, respectively) (Table 2).

During a year, the highest values of light intensity and photoperiod occur in MayJuly, while precipitation of atmospheric precipitation falls on August-September (Table 2).

The water transparency was estimated from the depth of visibility of the white Seki disk. Its values in the Regions 1-4 were selected from the reports on the separate expediitions of the Hydrometeorological Service and the fishing industry performed in various years. In Regions 1-4, the average values of the water transparency in individual months varied accordingly within the limits of $1-9,1-12,1-10$, and $1-12 \mathrm{~m}$. The smallest average transparency values of water $(1-2 \mathrm{~m})$ in these regions fall within the period January-April, and the highest values (10-12 m) - in November-December (Table 2).

The values of total flow rates calculated with the help of BOM (Table 3, Appendix) determine the expressed bilateral water exchange through the boundaries between Regions 1-4 and with open water areas of the Sea of Okhotsk. The range of water flow rate values varies within one to three orders of magnitude, taking into account the fluctuations in the thickness of the separated upper and lower layers of water in different months.

The water transfer in January-May in the surface layer from Region 1 to Region 2 is characterized by water flow rate values of $192.9-377.0 \mathrm{~km}^{3} / \mathrm{month}$, in June-August it is weakening (water flow rate values are reduced to $0.8-11.0 \mathrm{~km}^{3} / \mathrm{month}$ ), in the following months (September-December) - the water exchange is increasing (flow rate values increase to $200.4-419.0 \mathrm{~km}^{3} /$ month). For most part of a year, the reverse water transfer in the surface layer (from Region 2 to Region 1) is more active: the periods JanuaryMay and June-September are characterized by flow rate values, respectively 467.1644.6 and $64.9-103.4 \mathrm{~km}^{3} /$ month, and in October-December, the flow rate values are within $232.2-412.5 \mathrm{~km}^{3} /$ month, and comparable with the water transfer from Region 1 to Region 2. The intensity of the water transport in the lower layer (from Region 1 to Region 2 and backward transfer from Region 2 to Region 1) remains high throughout a year, as evidenced by fluctuations in different months of flow rate values - within 1221.6-2126.5 and $1382.4-2094.5 \mathrm{~km}^{3} /$ month (Table 3). 
Table 3. Long-term monthly values of flow rates at the boundary of Regions 1-4 (NESS), exchange with outer waters of the Sea of Okhotsk, vertical transport, and river runoff (all - in $\mathrm{km}^{3} / \mathrm{month}$ )

\begin{tabular}{|c|c|c|c|c|c|c|c|c|c|c|c|c|}
\hline $\begin{array}{l}\text { Transport } \\
\text { from }\end{array}$ & I & II & III & IV & V & VI & VII & VIII & IX & $\mathrm{X}$ & XI & XII \\
\hline \multirow{2}{*}{$1 \rightarrow 2$} & 377.0 & 313.3 & 356.4 & 304.9 & 192.9 & 6.1 & 0.8 & 11.0 & 200.4 & 253.6 & 419.0 & 284.6 \\
\hline & $\overline{1607.5}$ & $\overline{1739.6}$ & $\overline{1836.1}$ & $\overline{1773.3}$ & 2087.0 & $2 \overline{126.5}$ & $\overline{1885.8}$ & $\overline{1794.6}$ & $\overline{1221.6}$ & $\overline{1304.6}$ & $\overline{1565.2}$ & $\overline{1450.2}$ \\
\hline \multirow{2}{*}{$2 \rightarrow 1$} & 467.1 & 500.0 & 534.4 & 553.3 & 644.6 & 98.0 & 193.4 & 163.2 & 64.9 & 232.2 & 412.5 & 357.7 \\
\hline & $\overline{1576.4}$ & $\overline{1629.7}$ & $\overline{1752.8}$ & $\overline{1625.8}$ & $\overline{1738.8}$ & $\overline{2094.5}$ & $\overline{1728.9}$ & $\overline{1675.0}$ & $\overline{1382.4}$ & $\overline{1440.4}$ & $\overline{1753.3}$ & $\overline{1521.8}$ \\
\hline \multirow{2}{*}{$3 \rightarrow 1$} & 88.5 & 89.4 & 128.8 & 132.6 & 138.0 & 52.0 & 124.5 & 98.5 & 49.0 & 54.8 & 52.3 & 83.9 \\
\hline & $\overline{9.0}$ & $\overline{0.3}$ & $\overline{0.2}$ & $\overline{0.7}$ & $\overline{0.2}$ & $\overline{143.6}$ & $\overline{130.4}$ & $\overline{112.8}$ & $\overline{149.4}$ & $\overline{307.2}$ & $\overline{209.9}$ & $\overline{118.3}$ \\
\hline \multirow{2}{*}{$1 \rightarrow 3$} & 55.1 & 62.6 & 85.8 & 88.7 & 69.8 & 14.8 & 9.5 & 17.8 & 44.1 & 241.8 & 246.0 & 143.7 \\
\hline & $\overline{49.3}$ & $\overline{78.3}$ & $\overline{114.3}$ & $\overline{118.5}$ & $\overline{138.5}$ & $\overline{159.9}$ & $\overline{174.4}$ & $\overline{107.6}$ & $\overline{79.9}$ & $\overline{97.2}$ & $\overline{79.2}$ & $\overline{78.4}$ \\
\hline \multirow{2}{*}{$4 \rightarrow 2$} & 244.1 & 277.0 & 340.0 & 323.5 & 308.3 & 33.8 & 28.9 & 129.1 & $\underline{111.3}$ & 17.4 & 60.9 & $\underline{112.6}$ \\
\hline & $\overline{417.4}$ & $\overline{416.1}$ & $\overline{468.9}$ & $\overline{495.5}$ & $\overline{524.1}$ & $\overline{672.1}$ & $\overline{830.1}$ & $\overline{452.2}$ & $\overline{443.9}$ & $\overline{711.9}$ & $\overline{696.7}$ & $\overline{632.6}$ \\
\hline \multirow{2}{*}{$2 \rightarrow 4$} & 30.5 & 14.2 & 8.1 & 6.8 & 17.4 & 4.5 & 69.4 & 0.0 & 5.2 & 88.7 & 40.9 & 25.7 \\
\hline & $\overline{643.3}$ & $\overline{632.6}$ & $\overline{730.5}$ & $\overline{737.2}$ & $\overline{799.5}$ & $\overline{752.8}$ & $\overline{901.2}$ & $\overline{716.6}$ & $\overline{663.7}$ & $\overline{680.6}$ & $\overline{648.3}$ & $\overline{708.9}$ \\
\hline \multirow{2}{*}{$3 \rightarrow 4$} & 236.1 & 262.2 & 345.6 & 371.9 & 497.6 & 174.9 & 62.2 & 147.9 & 203.9 & 298.8 & 412.0 & 264.7 \\
\hline & $\overline{310.6}$ & $\overline{178.6}$ & $\overline{152.8}$ & $\overline{148.8}$ & $\overline{108.7}$ & $\overline{533.0}$ & $\overline{425.5}$ & $\overline{515.1}$ & $\overline{515.5}$ & $\overline{637.8}$ & $\overline{716.9}$ & $\overline{636.2}$ \\
\hline \multirow{2}{*}{$4 \rightarrow 3$} & 226.1 & 114.0 & 107.0 & 104.8 & 89.3 & 11.8 & 61.1 & 58.3 & 130.8 & 203.1 & 300.9 & 435.2 \\
\hline & $\overline{265.3}$ & $\overline{234.1}$ & $\overline{277.9}$ & $\overline{303.5}$ & $\overline{458.2}$ & $\overline{676.0}$ & $\overline{460.7}$ & $\overline{645.1}$ & $\overline{625.9}$ & $\overline{724.0}$ & $\overline{732.2}$ & $\overline{404.7}$ \\
\hline \multicolumn{13}{|c|}{ Exchange with outer water area - from the Sea of Okhotsk } \\
\hline \multirow{2}{*}{$1 \rightarrow \mathrm{N}$} & 387.8 & 361.0 & 354.1 & 375.8 & 493.3 & 73.8 & 265.0 & 284.4 & 174.8 & 154.9 & 302.3 & 340.5 \\
\hline & $\overline{357.1}$ & $\overline{328.4}$ & $\overline{312.4}$ & $\overline{320.2}$ & $\overline{224.2}$ & $\overline{476.6}$ & $\overline{629.3}$ & $\overline{484.6}$ & $\overline{552.7}$ & $\overline{517.9}$ & $\overline{488.0}$ & $\overline{610.7}$ \\
\hline \multirow{2}{*}{$\mathrm{N} \rightarrow 1$} & 108.8 & 72.5 & 64.2 & 53.8 & 71.5 & $\underline{33.2}$ & $\underline{36.6}$ & $\underline{58.8}$ & 64.1 & 145.7 & $\underline{151.0}$ & $\underline{75.6}$ \\
\hline & $\overline{757.2}$ & $\overline{736.0}$ & $\overline{733.8}$ & $\overline{757.3}$ & $\overline{822.3}$ & $\overline{674.3}$ & $\overline{1014.1}$ & $\overline{891.2}$ & $\overline{766.5}$ & $\overline{674.5}$ & $\overline{785.0}$ & $\overline{1018.3}$ \\
\hline \multirow{2}{*}{$2 \rightarrow \mathrm{N}+\mathrm{E}$} & 600.5 & 716.5 & $\underline{581.0}$ & $\underline{510.4}$ & 499.4 & 38.9 & 5.8 & 38.0 & 216.7 & 103.3 & 327.6 & 326.1 \\
\hline & $\overline{4661.7}$ & $\overline{4427.6}$ & $\overline{4601.3}$ & $\overline{4043.4}$ & $\overline{4287.4}$ & $\overline{4936.3}$ & $\overline{4832.6}$ & $\overline{4493.2}$ & $\overline{4108.8}$ & $\overline{4796.2}$ & $\overline{4900.6}$ & $\overline{4285.7}$ \\
\hline \multirow{2}{*}{$\mathrm{N}+\mathrm{E} \rightarrow 2$} & 1127.6 & 1042.6 & 1030.7 & $\underline{948.8}$ & 1060.0 & 130.6 & 324.1 & 293.0 & 280.8 & 457.6 & $\underline{706.6}$ & 741.1 \\
\hline & $\overline{4339.7}$ & $\overline{4263.3}$ & $\overline{4029.1}$ & $3 \overline{502.2}$ & $\overline{4522.6}$ & $\overline{4703.0}$ & $\overline{4342.5}$ & $\overline{4019.9}$ & $3 \overline{3920.3}$ & $\overline{4297.2}$ & $\overline{4390.5}$ & $3 \overline{3758.8}$ \\
\hline \multirow{2}{*}{$4 \rightarrow E+S$} & 1469.5 & 1023.5 & 1013.0 & 976.6 & 1282.8 & 294.0 & 344.0 & 397.1 & 646.4 & 1190.8 & 2072.4 & 1676.0 \\
\hline & $2 \overline{2452.5}$ & $2 \overline{2284.6}$ & $2 \overline{2438.5}$ & $2 \overline{2375.2}$ & $\overline{2596.4}$ & $\overline{4391.3}$ & $\overline{4377.9}$ & $\overline{4297.9}$ & $\overline{4041.6}$ & $3 \overline{593.5}$ & $3 \overline{150.0}$ & $\overline{2502.1}$ \\
\hline \multirow{2}{*}{$\mathrm{E}+\mathrm{S} \rightarrow 4$} & $\underline{595.5}$ & $\underline{719.8}$ & 847.8 & $\underline{900.5}$ & 1120.8 & 290.3 & $\underline{717.4}$ & $\underline{927.3}$ & $\underline{984.6}$ & $\underline{644.3}$ & $\underline{735.8}$ & 629.6 \\
\hline & $3 \overline{307.0}$ & $2 \overline{570.2}$ & $\overline{2582.5}$ & $\overline{2428.3}$ & $2 \overline{2773.7}$ & $\overline{4377.4}$ & $\overline{3996.9}$ & $3 \overline{773.7}$ & $\overline{3698.5}$ & $\overline{4096.5}$ & $\overline{4413.7}$ & $\overline{3502.0}$ \\
\hline \multicolumn{13}{|c|}{ Vertical transport in water area: («+» means upward, «-» means downward) } \\
\hline 1 & +238.8 & +45.8 & -77.4 & -86.9 & -207.3 & +12.8 & -4.1 & -57.5 & +356.6 & +311.5 & +472.1 & +529.3 \\
\hline 2 & -842.9 & -901.9 & -931.4 & -870.4 & -583.5 & -68.7 & -164.9 & -230.4 & -291.7 & -350.9 & -417.3 & -553.8 \\
\hline 3 & -85.4 & -49.9 & -46.3 & -35.6 & +20.8 & +260.9 & +110.6 & +144.9 & +55.1 & +65.4 & +76.3 & -156.2 \\
\hline 4 & +387.6 & +166.6 & +105.0 & +94.7 & +88.1 & +77.7 & +57.1 & +21.7 & +261.8 & +374.0 & +567.6 & +649.0 \\
\hline \multicolumn{13}{|c|}{ River runoff - Tym' River } \\
\hline 3 & 0.048 & 0.035 & 0.036 & 0.094 & 0.935 & 0.511 & 0.177 & 0.164 & 0.187 & 0.228 & 0.109 & 0.067 \\
\hline
\end{tabular}

The intensity of surface water transfer in different months in the coastal zone (from Region 3 to Region 1 and reverse transfer - from Region 1 to Region 3) is lower, and is characterized by fluctuations in water flow rates, respectively, within 52.0-138.0 and 
9.5-246.0 $\mathrm{km}^{3} / \mathrm{month}$. The water transfer from Region 3 to Region 1 in the lower layer in January-May is insignificant (fluctuations in flow rates are in the range $0.2-9.0 \mathrm{~km}^{3}$ / month), and in June-December its intensity is significantly higher (their values are $112.8-307.2 \mathrm{~km}^{3} / \mathrm{months}$ ). Reverse water transfer in the lower layer (from Region 1 to Region 3 ) is valid for a year and is characterized by fluctuations of flow rates in the range of 49.3-174.4 $\mathrm{km}^{3} /$ months (Table 3 ).

The transfer of surface waters (at the border of Regions 3 and 4) during a year is more active from coastal Region 3 to Region 4 with fluctuations of flow rate $\left(\mathrm{km}^{3} / \mathrm{month}\right)$ values in November-May, June-August and September-October within 262.2-497.6, 62.2-174.9, and 203.9-298.8 respectively. Reverse transfer of surface waters (from Region 4 to Region 3) during the indicated periods of a year occurs at the water flow rates that vary within 89.3-435.2, 11.8-61.1, and 130.8-203.1 respectivele. On the contrary, in the lower layer the intensity of the water transport during a year is generally higher from the Region 4 to Region 3 (the range of flow rate fluctuations in certain months is $234.1-732.2 \mathrm{~km}^{3} /$ month) than the reverse water transfer from Region 3 to Region 4 (108.7-716.9 km³ month) (Table 3).

The transfer of surface waters in the moraine part of the NESS (at the border of Regions 2 and 4) is more intensive from Region 4 to Region 2 (with fluctuations in water flo rates in January-May, June-August and September-December, respectively, 244.1$340.0,28.9-129.1$, and 17.4-112.6 $\mathrm{km}^{3} /$ month) in comparison with the reverse water transfer from Region 2 to Region 4 in the same periods of a year, however, it occurs more intensively from Region 2 to Region 4 (with fluctuations in water flow rates in individual months within 632.6-901.2 km³/month) than from Region 4 to Region 2 (416.1-830.12 $\mathrm{km}^{3} /$ month) (Table 3).

During a year, there is also a bilateral water exchange through the boundaries of the NESS regions with open water areas of the Sea of Okhotsk. The calculations took into account the water flow rate values estimated with the help of BOM, which determine the water exchange in the North of the NESS (with Region 1), as well as the total water exchange in the North and East (with Region 2) and in the East and South (with Region 4).

The intensity of surface water transfer from Region 1 to the North from November to May is characterized by water flow rates of $302.3-493.3 \mathrm{~km}^{3} / \mathrm{month}$; in June, the water transfer slows down (the water flow rate is reduced to $73.8 \mathrm{~km}^{3} / \mathrm{month}$ ), and from July to October, the water exchange increases (at water flow rates of $154.9-284.4 \mathrm{~km}^{3} / \mathrm{month}$ ). The reverse water transfer (from the North to the Region 1) is carried out with lower water flow rates: in October-February they are within $72.5-151.0 \mathrm{~km}^{3} / \mathrm{month}$, and in the remaining months - are reduced to $33.2-64.2 \mathrm{~km}^{3} /$ month.

The water transfer from Region 2 to the North and East in January-May is characterized by flow rate values of $499.4-716.5 \mathrm{~km} 3 /$ month; in May-July, its intensity drops significantly (5.8-38.9); and in August-December, it increases (103.3-327.6 km month). The reverse water transfer to the Region 2 (in January-May) is developing quite actively (at a water flow rates of 948.8-1127.6); in June-September, its activity is weakening (130.6-324.1), and in October-December, it is increasing (457.6-741.1 $\mathrm{km}^{3} /$ month). 
From Region 4, the total water transfer develops in the direction of the East and South from October to May with increased flow rates (976.6-2072.4 km³/month); and in June-September - with slightly slower flow rates (294.0-646.4 km³/month). In the most part of a year, the water transfer to the Region 4 from the East and South is active, and it is characterized by water flow rate values of $595.5-1120.8 \mathrm{~km}^{3} / \mathrm{month}$, and only in June, the water transfer is carried out at a lower speed $\left(290.3 \mathrm{~km}^{3} / \mathrm{month}\right)$.

In the lower layer throughout a year, a high two-way water transport was noted across the boundaries of Regions 1, 2 and 4 of the NESS with open water areas of the Sea of Okhotsk. During a year, the transfer of waters from Region 1 to the North is developing quite actively (with water flow rates of $224.2-629.3 \mathrm{~km}^{3} / \mathrm{month}$ ), but the reverse water transfer to Region 1 is even more intensive (674.3-1014.1 km³/month) (Table 3).

During a year, the water transfer from Region 2 in the direction to the North and East is much higher and is characterized by water flow rates of $4043.4-4936.3 \mathrm{~km}^{3}$ / month, the return water transfer to Region 2 passes with slightly less activity (3502.2$\left.4390.5 \mathrm{~km}^{3} / \mathrm{month}\right)$.

Two-way water exchange at the border of the Region 4-E/S is also carried out with high water flow rates: in the direction from Region 4 and in the opposite stream these rates vary accordingly in the ranges $2284.6-4391.3$ and $2428.3-4413.7 \mathrm{~km}^{3} / \mathrm{month}$ (Table 3 ).

The estimated values of vertical water exchange between the upper and lower layers are significantly different: the total range of changes in water flow rate values in Regions 1-4 are 4.1-529.3, 68.7-931.4, 20.8-260.9, 21.7-649.0 km³/month respectively. The values of vertical exchange are the least in Regions 1-4 in July, June, May, and August respectively, and they are elevated in December, March, June, and December. The highest values of vertical water exchange occur in Regions 1-4, respectively, in September-January (238.8-529.3 km³/month), December-May (553.8-931.4), JuneAugust (110.6-260.9), and September-January (261.8-649.0 km³/month) (Table 3).

Further in the text, the results of intra-annual variations in the calculated concentrations of the main $\mathrm{N}, \mathrm{P}, \mathrm{Si}$, substances for the second calculated year are presented and discussed. It should be noted a stable tendency of «correspondence» of the concentrations of substances (at the beginning and at the end of a year), which confirms the balance of these processes for the mean long-term conditions in the ecosystem of the NESS.

\section{Calculation of BS inputs in waters of Regions 1-4}

The input of BS into the sea water area occurs with the runoff of the Tym' River (to Region 3), from open areas of the Sea of Okhotsk (to Regions 2 and 4), as well as from neighboring water areas and with atmospheric precipitation (in Regions 1-4).

River runoff to the sea waters of the Region 3. Annual flow of the Tym' River is $2.591 \mathrm{~km}^{3} /$ year, the average monthly flow rate is $0.216 \mathrm{~km}^{3} /$ month. It is the smallest in February (0.035) and the largest in May and June (0.935 and $\left.0.511 \mathrm{~km}^{3} / \mathrm{month}\right)$ (Table 3). According to the accepted average concentrations of BS as well as water flow rates, the monthly BS inputs into the surface layer of sea water in Region 3 were calculated. It 
should be noted the following peculiarities of the BS inputs with river runoff into sea waters:

- the annual BS inputs with the runoff of Tym' River into the sea waters of Region 3 are: $\mathrm{DOC}-5.97$ thousand tons of $\mathrm{C}$; DON $-0.12, \mathrm{NH}_{4}-<0.01, \mathrm{NO}_{2}-<0.01, \mathrm{NO}_{3}-$ $0.08, \mathrm{ND}-0.30$ thousand tons of N; DIP and DOP - on $0.02, \mathrm{PD}-0.09$ thousand tons of $\mathrm{P}$; DISi - 2.38 thousand tons of $\mathrm{Si}$;

- $50-79.5 \%$ of the annual BS inputs with river runoff into the waters of Region 3 is in May-June; in the winter months it is the smallest $(<10 \%)$; for the summer and autumn months, there are a total $\sim 15-25 \%$ of the annual BS inputs.

Transfer of BS at bilateral water exchange between Regions 1-4. Table 4 shows the calculation results of the BS inputs in each region during water exchange through the boundaries between Regions 1-4, namely: the amplitude ranges of the monthly transfer, the final annual and «net» transfer (taking into account the losses to remove the BS with a counterflow of water). For Region 1, these carry-off losses are significantly lower than their input for water exchange with neighboring areas, in Region 3 - it is higher only for a number of substances (DOC, $\mathrm{ND}, \mathrm{PD}, \mathrm{NH}_{4}, \mathrm{NO}_{2}$, and DIP), and in Regions 2 and 4 - the input almost all $\mathrm{BS}$ is less of their outputs in the neighboring areas.

Transfer of BS in bilateral water exchange between the open waters of the Sea of Okhotsk and Regions 1-4. Table 5 shows the results of calculations of the BS inputs in Regions 1, 2 and 4 during water exchange with open areas of the Sea of Okhotsk, in which the substance concentrations in individual months were taken as a result of previous calculations (Leonov, Sapozhnikov, 1997).

The BS inputs with atmospheric precipitation into the surface layer of sea water in Regions 1-4 is estimated from monthly precipitation data (Table 2) and taken as constant concentrations of $\mathrm{BS}$ in atmospheric moisture ( $\mathrm{DOC}=2 \mathrm{mg} \mathrm{C} / \mathrm{L}, \mathrm{DON}=0.1, \mathrm{ND}=0.1$; $\mathrm{NH}_{4}=0.3 ; \mathrm{NO}_{2}=0.01 ; \mathrm{NO}_{3}=0.25 \mathrm{mg} \mathrm{N} / \mathrm{L} ; \mathrm{DIP}=0.015 ; \mathrm{DOP}=0.01 ; \mathrm{PD}=0.01 \mathrm{mg}$ $\mathrm{P} / \mathrm{L})$. The least amount of BS comes in the marine environment with atmospheric moisture in February: for Regions 1-2 and 3-4 these amounts in relation to the annual BS input are 3.6 and $5.0 \%$, respectively, and the greatest amount of BS with atmospheric moisture comes in September (in Regions 1-2 and 3-4 - according to 14.1 and $11.5 \%$ of annual BS inputs respectively).

\section{Analysis of calculated dynamics of BS concentrations in waters of Regions 1-4}

The calculated intra-annual dynamics of BS concentrations and organism biomasses are shown in Fig. 2-5.

Annual changes of the concentrations of $\mathrm{NH}_{4}$ (Fig. 2a) and $\mathrm{NO}_{2}$ (Fig. 2b) in the aquatic environment are very similar, since these variables are closely interrelated. The initial values of the concentrations of $\mathrm{NH}_{4}$ and $\mathrm{NO}_{2}$ are small and vary in the waters of Regions $1-4$ within $0.0002-0.001 \mathrm{mg} \mathrm{N} / \mathrm{L}$.

During a year, one expressed maximum of the concentrations of $\mathrm{NH}_{4}$ is recorded in Regions 1-4: on the 185th, 171st, 178th, and 171st days $(0.0285,0.0198,0.0037$ and $0.0221 \mathrm{mg} \mathrm{N} / \mathrm{L}$ ), respectively. In the second half of a year, three synchronous small peaks 
of $\mathrm{NH}_{4}$ concentrations can be identified in Regions 2 and 4. They are also related with clear $\mathrm{NO}_{2}$ maxima formed after the formation of intermediate $\mathrm{NH}_{4}$ peaks. In Regions $1-4, \mathrm{NO}_{2}$ maxima fall respectively on the $188 \mathrm{th}, 173 \mathrm{rd}, 185 \mathrm{th}$, and 176 th days $(0.0079$, $0.0060,0.0015$, and $0.0068 \mathrm{mg} \mathrm{N} / \mathrm{L}$ ).

Table 4. Estimated number of BS entering the upper water layer monthly (thousand tons of Element /month) and per year (thousand t of Element/year) into waters of regions 1-4 (NESS) at the bilateral water exchange across the boundaries between these regions ( 1 - the range of changes by months; 2 - the annual input; 3 - the «net» input for a year, or the difference between the input and output by water flow to neighboring areas

\begin{tabular}{|c|c|c|c|c|c|c|}
\hline \multirow{2}{*}{$\begin{array}{c}\text { Para- } \\
\text { meter }\end{array}$} & \multicolumn{3}{|c|}{ Region 1 } & \multicolumn{3}{c|}{ Region 2 } \\
\cline { 2 - 7 } & 1 & 2 & 3 & 1 & & 3 \\
\hline DOC & $20.39-1258.2$ & 7248.57 & 6771.21 & $0.00-694.53$ & 3633.57 & -3577.04 \\
\hline DON & $0.00-171.44$ & 644.83 & 238.00 & $7.25-180.88$ & 1253.67 & 871.55 \\
\hline ND & $1.06-13.04$ & 74.28 & 64.15 & $0.00-13.11$ & 26.09 & -54.62 \\
\hline PD & $0.01-1.50$ & 4.03 & 2.71 & $0.00-0.28$ & 0.73 & -3.66 \\
\hline DOP & $0.01-3.53$ & 11.41 & 7.85 & $0.01-4.41$ & 17.91 & 7.06 \\
\hline NH4 & $0.01-1.12$ & 5.62 & 4.53 & $0.02-0.55$ & 2.46 & -3.31 \\
\hline NO2 & $0.00-0.56$ & 2.73 & 2.36 & $0.01-0.16$ & 1.10 & -1.33 \\
\hline NO3 & $0.01-26.97$ & 74.55 & 67.68 & $0.12-16.68$ & 61.85 & -4.45 \\
\hline DIP & $0.29-11.25$ & 47.76 & 34.53 & $0.03-7.98$ & 39.81 & -9.45 \\
\hline DISi & $0.00-28.95$ & 77.79 & 8.04 & $0.24-57.23$ & 240.90 & 211.85 \\
\hline
\end{tabular}

\begin{tabular}{|c|c|c|c|c|c|c|}
\hline \multirow{2}{*}{$\begin{array}{c}\text { Para- } \\
\text { meter }\end{array}$} & \multicolumn{3}{|c|}{ Region 3 } & \multicolumn{3}{c|}{ Region 4 } \\
\cline { 2 - 7 } & 1 & 2 & 3 & 1 & 2 & 3 \\
\hline DOC & $0.00-514.49$ & 1843.15 & 699.98 & $0.00-268.58$ & 1252.04 & -3740.39 \\
\hline DON & $0.00-124.55$ & 349.84 & -1073.67 & $0.19-253.30$ & 1158.43 & -37.35 \\
\hline ND & $0.02-8.13$ & 40.24 & 38.19 & $0.00-3.83$ & 8.39 & -47.82 \\
\hline PD & $0.00-0.75$ & 2.23 & 1.42 & $0.00-0.63$ & 1.15 & -0.47 \\
\hline DOP & $0.01-1.96$ & 4.42 & -11.02 & $0.00-1.98$ & 17.91 & -8.38 \\
\hline NH4 & $0.00-0.48$ & 1.75 & 1.20 & $0.00-0.30$ & 1.34 & -1.80 \\
\hline NO2 & $0.00-1.46$ & 1.68 & 1.12 & $0.00-0.11$ & 1.10 & -0.64 \\
\hline NO3 & $0.00-2.12$ & 5.24 & -58.77 & $0.00-16.07$ & 55.20 & -7.01 \\
\hline DIP & $0.00-10.61$ & 40.26 & 32.36 & $0.00-2.79$ & 9.16 & -53.92 \\
\hline DISi & $0.00-24.98$ & 61.69 & -247.51 & $0.00-57.23$ & 202.83 & -46.64 \\
\hline
\end{tabular}

The initial values of $\mathrm{NO}_{3}$ concentrations in Regions $1-4$ differ and amount to 0.030, $0.028,0.036$, and $0.020 \mathrm{mg} \mathrm{N} / \mathrm{L}$, respectively. In general, the same trends are observed in the dynamic of $\mathrm{NO}_{3}$ concentrations in the waters of all regions. In the first half of a year, $\mathrm{NO}_{3}$ is accumulated in water environment, and in Regions 1 and 2, the rates of $\mathrm{NO}_{3}$ accumulatiod are higher, and $\mathrm{NO}_{3}$ peaks $(0.0640$ and $0.0551 \mathrm{mg} \mathrm{N} / \mathrm{L})$ are noted here respectively on 168th and 120th days. In Regions 3 and 4, the highest concentrations of $\mathrm{NO}_{3}$ were recorded respectively at $152 \mathrm{nd}$ and 185 th days $(0.0422$ and $0.463 \mathrm{mg} \mathrm{N} / \mathrm{L})$. During the period 183-218th days, concentrations of $\mathrm{NO}_{3}$ are sharp decreased (up to 
0.7-2.8 $\mu \mathrm{g} \mathrm{N} / \mathrm{L}$ ) in waters of all regions. These small concentrations of $\mathrm{NO}_{3}$ persist till 292 nd day in the waters of Regions $1-4$. The content of $\mathrm{NO}_{3}$ concentrations in the aquatic environment are restored to their original values in the period autumn - the end of a year (Fig. 2c).

Table 5. Estimated amount of BS entering the upper water layer monthly (thousand tons of Element/month) and for a year (thousand t of Element/year) into waters of Regions 1, 2 and 4 (NESS) at the bilateral water exchange through boundaries with the open waters of the Sea of Okhotsk ( 1 - range of changes by months, 2 - annual input, 3 - «net» annual input, or difference between input and output by water flow to open water areas of the sea)

(dash - flux was not estimated)

\begin{tabular}{|c|c|c|c|c|c|c|c|c|c|}
\hline \multirow{2}{*}{$\begin{array}{c}\text { Para- } \\
\text { meter }\end{array}$} & \multicolumn{3}{|c|}{ Region 1 } & \multicolumn{3}{c|}{ Region 2 } & \multicolumn{3}{c|}{ Region 4 } \\
\cline { 2 - 10 } & 1 & 2 & 3 & 1 & 2 & 3 & 1 & 2 & 3 \\
\hline DOC & $1.67-30.95$ & 139.79 & -4335.26 & $398.85-3534.06$ & 25151.06 & 15487.09 & $85.24-1957.54$ & 11539.78 & 8107.60 \\
\hline DON & $0.04-3.27$ & 10.24 & -2106.08 & $0.09-6.32$ & 29.71 & -1731.35 & $14.22-304.08$ & 1445.96 & 460.36 \\
\hline ND & $0.01-2.94$ & 3.83 & -37.75 & $0.10-5.27$ & 16.91 & 10.54 & $0.11-5.04$ & 19.65 & -6.67 \\
\hline PD & $0.01-0.07$ & 0.33 & -3.22 & $0.03-2.03$ & 7.80 & 1.43 & $0.11-1.13$ & 6.02 & 3.94 \\
\hline DOP & $0.01-0.17$ & 0.73 & -38.74 & $0.01-5.99$ & 13.91 & -31.66 & $0.06-7.64$ & 35.35 & 29.40 \\
\hline NH4 & $0.01-0.09$ & 0.49 & -5.38 & $0.04-0.60$ & 4.38 & -1.61 & $0.10-0.94$ & 4.66 & 3.25 \\
\hline NO2 & $0.01-0.04$ & 0.21 & 1.73 & $0.03-0.23$ & 1.77 & -1.45 & $0.03-0.59$ & 3.60 & 3.23 \\
\hline NO3 & $0.04-3.38$ & 13.39 & -102.98 & $2.65-45.03$ & 246.18 & 104.47 & $0.92-20.98$ & 111.84 & 92.27 \\
\hline DIP & $0.00-0.26$ & 1.14 & -66.37 & $0.01-2.71$ & 12.96 & -81.24 & $0.17-16.43$ & 77.90 & 37.05 \\
\hline DISi & $0.06-0.87$ & 4.80 & -224.32 & $0.35-15.86$ & 99.46 & -62.63 & $2.80-125.75$ & 720.41 & 617.62 \\
\hline
\end{tabular}

In the first part of a year, the dynamics of the total mineral $\mathrm{N}\left(\mathrm{N}_{\min }\right)$ concentrations in the waters of Regions 1-4 oscillates synchronously with changes in the $\mathrm{NO}_{3}$ concentrations as the dominant fraction of $\mathrm{N}_{\min }$. In the middle of a year, expressed maxima of $\mathrm{N}_{\min }$ contents were noted: in Regions 1 and 3 - on the 185th day (0.0971 and $0.0469 \mathrm{mg} \mathrm{N} / \mathrm{L})$ and in Regions 2 and $4-$ on the 174 th day $(0.0747$ and $0.0668 \mathrm{mg} \mathrm{N} / \mathrm{L})$, which is a consequence of the increased concentrations of $\mathrm{NH}_{4}$ and $\mathrm{NO}_{2}$, fixed in these regions in almost the same periods of time. In the last third of a year, the dynamics of $\mathrm{N}_{\min }$ concentrations coincides practically with the $\mathrm{NO}_{3}$ dynamics since the content of $\mathrm{NH} \mu$ and $\mathrm{NO}_{2}$ remains low in the second half of a year and does not significantly affect the total $\mathrm{N}_{\min }$ content in different regions of the sea (Fig. 2d)

In the waters of coastal Regions ( 1 and 3 ) and in remoted from the coast Regions (2 and 4), concentrations of DON differ significantly. In the waters of Regions 1 and 3 , the concentration of DON is higher for most part of a year. Annual amplitude of DON fluctuations in these regions are smaller (respectively, within 0.6423-0.3942 and $0.6400-0.4871 \mathrm{mg} \mathrm{N} / \mathrm{L}$ ) in comparison with Regions 2 and 4. The initial DON concentrations in the waters of Regions 2 and 4 are 0.5 and $0.23 \mathrm{mg} \mathrm{N} / \mathrm{L}$ respectively. In Region 2 during the first half of a year, the DON content decreases to $0.2092 \mathrm{mg} \mathrm{N} / \mathrm{L}$, and in Region 4, it practically does not change. In summer period, the DON content in the waters of Regions 2 and 4 increases significantly: in the Region 2 - to $0.5738 \mathrm{mg} \mathrm{N} / \mathrm{L}$ (at 274th day), and in the Region 4 - to $0.7538 \mathrm{mg} \mathrm{N} / \mathrm{L}$ (at 245th day). By the end of a year, 
the content of DON in the waters of Regions 2 and 4 is decreasing and approaching the initial values (Fig. 2e).

(a)

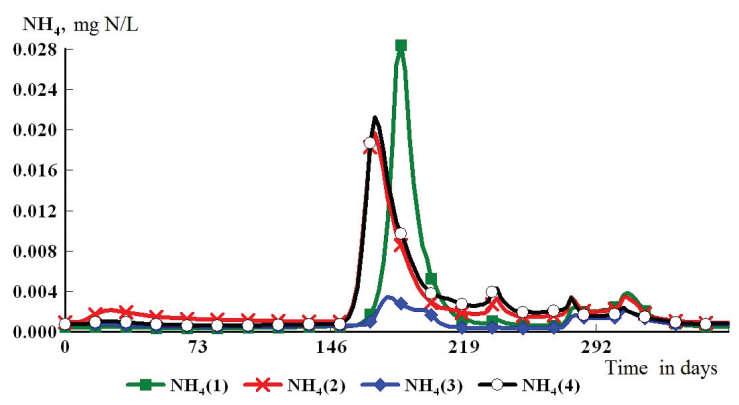

(c)

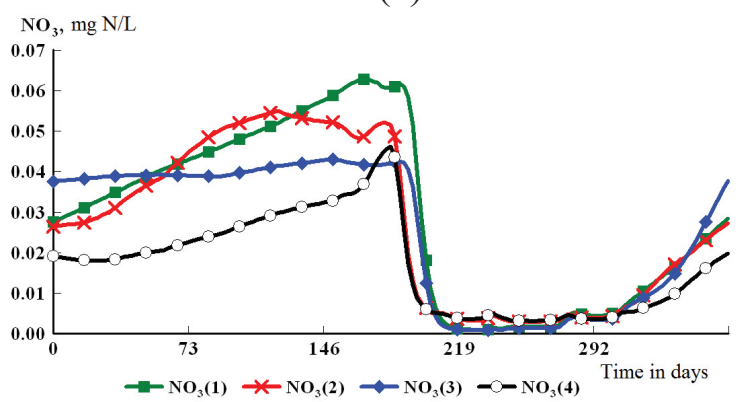

(e)

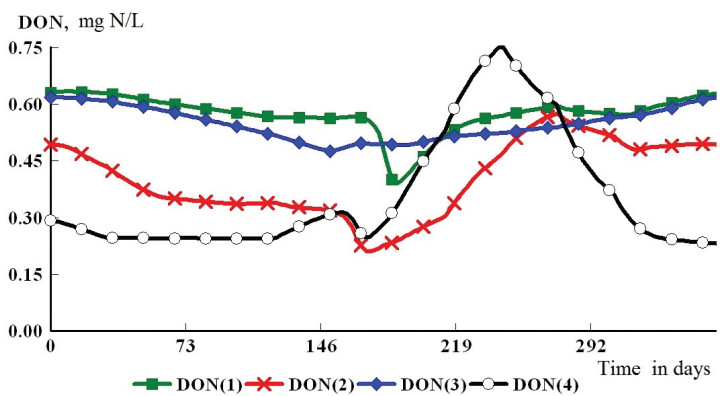

(b)

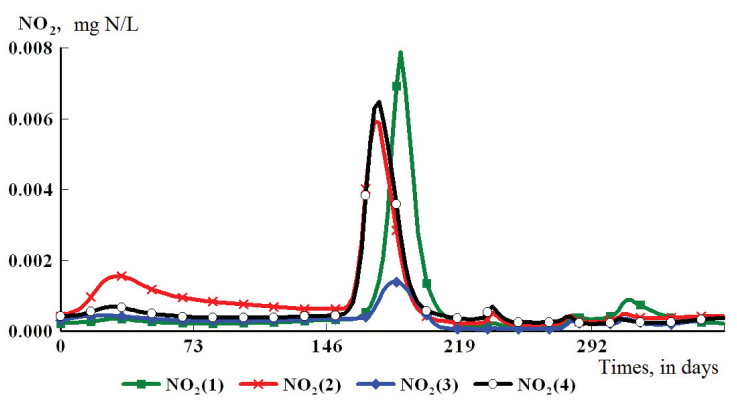

(d)

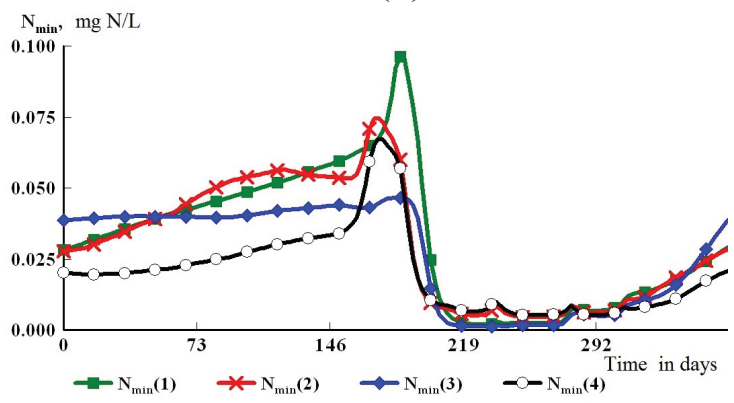

(f)

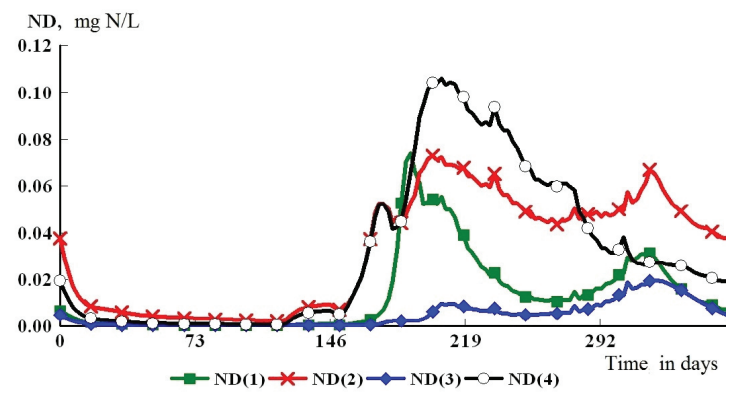

Fig. 2. Dynamics of the $\mathrm{N}$ form concentrations for the second calculated year: $\mathrm{NH}_{4}$ (a), $\mathrm{NO}_{2}$ (b), $\mathrm{NO}_{3}$ (c), $\mathrm{N}_{\min }(\mathrm{d}), \mathrm{DON}(\mathrm{e}), \mathrm{ND}$ (f) in the waters of Regions 1-4 (NESS)

In coastal waters (Regions 1 and 3), the initial concentrations of ND are lower (0.007 and $0.005 \mathrm{mg} \mathrm{N} / \mathrm{L}$ ) than in Regions 2 and 4 (0.038 and $0.02 \mathrm{mg} \mathrm{N} / \mathrm{L})$. In Regions $1-4$, the general trend in the decreasing of ND concentrations persists in JanuaryFebruary, and the ND content in Regions 1 and 3 decreases to $0.1-0.2 \mu \mathrm{g} \mathrm{N} / \mathrm{L}$, and in Regions 2 and 4 - to 0.9-3.2 $\mu \mathrm{g} \mathrm{N} / \mathrm{L}$ on 60th day. By the beginning of the second half of a year and further till the end of autumn, two maximal concentrations of ND are formed: in Region 1 - on the 190th and 320th days ( 0.0745 and $0.0312 \mathrm{mg} \mathrm{N} / \mathrm{L})$, in Region 2 - on the 207th and 320th days (0.0721 and 0.0666), in the Region $4-$ on the 176th and 207th days $(0.0530$ and $0.1060 \mathrm{mg} \mathrm{N} / \mathrm{L})$. In Region 3, the highest concentrations of ND were significantly lower, and they were noted on the 221nd and 322nd days (0.0073 and 0.0193 mg N/L respectively) (Fig. 2f). 
In the first half of a year in the waters of Regions 1 and 2, the change in DIP concentrations differs little from each other, showing fluctuations in ranges of 0.01910.0220 and $0.0172-0.0236 \mathrm{mg} \mathrm{P} / \mathrm{L}$ respectively. In the waters of Regions 3 and 4 , the DIP concentrations varied between $0.0050-0.0154$ and $0.0086-0.0154 \mathrm{mg} \mathrm{P} / \mathrm{L}$ respectively. In the second part of a year, the pattern of changes in DIP concentrations in the waters of each region is very specific. In the Region 1, to 209 days, the DIP content is reduced on the 209th day to a minimum $(0.0070 \mathrm{mg} \mathrm{P} / \mathrm{L})$, then the highest concentration of DIP $(0.0227 \mathrm{mg} \mathrm{P} / \mathrm{L})$ is reached by $312 \mathrm{nd}$ day, and by the end of a year, it gradually decreases to $0.0190 \mathrm{mg} \mathrm{P} / \mathrm{L}$. In Region 2, an intermediate minimum of the DIP content $(0.0135 \mathrm{mg}$ $\mathrm{P} / \mathrm{L}$ ) was noted at the 192nd day, and after which the DIP concentration increased to its maximum by 269 th day $(0.0407 \mathrm{mg} \mathrm{P} / \mathrm{L})$, then decreased to 346th day (up to $0.0150 \mathrm{mg}$ $\mathrm{P} / \mathrm{L}$ ) and by the end of the year it increases to $0.0206 \mathrm{mg} \mathrm{P} / \mathrm{L}$. In Region 3, the DIP content reaches its maximum at the 188 th day $(0.0160 \mathrm{mg} \mathrm{P} / \mathrm{L})$, after which its gradual decrease begins and by the end of a year its concentration drops to $0.0019 \mathrm{mg}$ P/L. In Region 4, the maximum DIP concentration $(0.0463 \mathrm{mg} \mathrm{P} / \mathrm{L})$ was observed on the 245 th day, then the DIP content was reduced to $0.0045 \mathrm{mg} \mathrm{P} / \mathrm{L}$ (344th day), and by the end of a year, it increased to $0.0113 \mathrm{mg}$ P/L (Fig. $3 \mathrm{a}$ ).

In almost first half of a year, the DOP concentrations in the waters of Regions 1, 3 and 4 are without significant changes and retains its highest values $(0.0167,0.0079$ and $0.0077 \mathrm{mg} \mathrm{P} / \mathrm{L}$ respectively). A sharp decrease in DOP concentrations in the waters of Regions 3 and 4 occurs from the 160th and by the 175th days (they drop to $<1 \mu \mathrm{g} P / \mathrm{L}$ ), while in Region 1, the decrease of the DOP concentration occurs from 175th to 190th days (down to $<1 \mu \mathrm{g}$ P/L). In Region 2, the decrease in DOP concentration occurs from 7 to 171 st days: during this period, the DOP concentration decreases from 22.1 to $<1 \mu \mathrm{g}$ $\mathrm{P} / \mathrm{L}$. In all regions, low DOP concentrations persist up to $\sim 300$ days. Over the past two months before the end of a year, in the waters of Regions 1-4, the DOP concentrations have increased (correspondingly to $0.0151,0.0205,0.0056$, and $0.0054 \mathrm{mg} \mathrm{P} / \mathrm{L}$ ), and these values are close to those taken at the beginning of a year (Fig. 3 b).

Since the beginning of a year, the PD content has been sharply reduced, and already at 5 day, low concentrations (in the order of $0.2-0.8 \mu \mathrm{g} \mathrm{P} / \mathrm{L}$ ) are established in the water of Regions 1-4. They are retained in the waters of all regions during the first half of a year, then in the waters of Regions 1, 2 and 4 they increase to $1.5 \mu \mathrm{g} \mathrm{P} / \mathrm{L}$, and in Region 3 , they remain low for a few months $(<1 \mu \mathrm{g} / \mathrm{L})$. However, during a year, synchronous short-term maxima of PD contents are recorded in Regions 1-4 in the background of low concentrations of PD: by 236th day $(1.5,3.1,0.6$, and $3.67 \mu \mathrm{g} \mathrm{P} / \mathrm{L})$, by 279 th day $(2.25$, $3.37,1.76$, and $2.59 \mu \mathrm{g} \mathrm{P} / \mathrm{L})$, by the 308th day $(3.85,3.34,3.03$, and $2.03 \mu \mathrm{g} \mathrm{P} / \mathrm{L})$. In the past two months, individual PD maxima in the waters of Regions $1-3$ have been formed at different times: respectively, on the $322 \mathrm{nd}$ day $(4.58 \mu \mathrm{g} \mathrm{P} / \mathrm{L})$, on the 324 th day (7.10) and on the 332nd day $(2.57 \mu \mathrm{g} \mathrm{P} / \mathrm{L})$. By the end of a year, the concentrations of PD in the waters of Regions 1-3 decrease accordingly to 2.30, 6.17, and $1.06 \mu \mathrm{g} \mathrm{P} / \mathrm{L}$, and in Region 4 they increase to $2.66 \mu \mathrm{g} \mathrm{P} / \mathrm{L}$ (Fig. $3 \mathrm{c}$ ). 
(a)

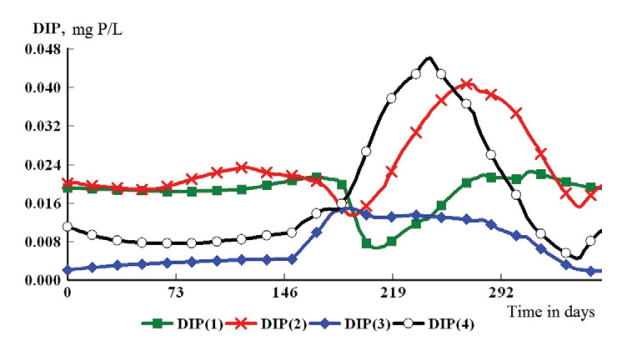

(b)

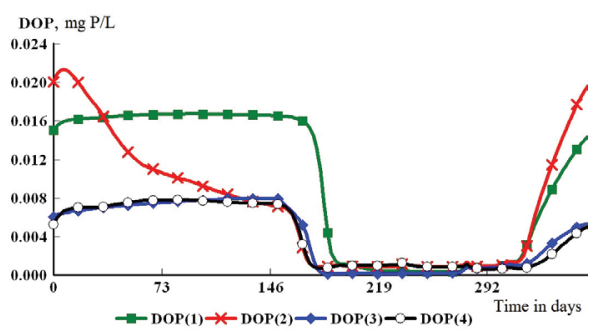

(c)

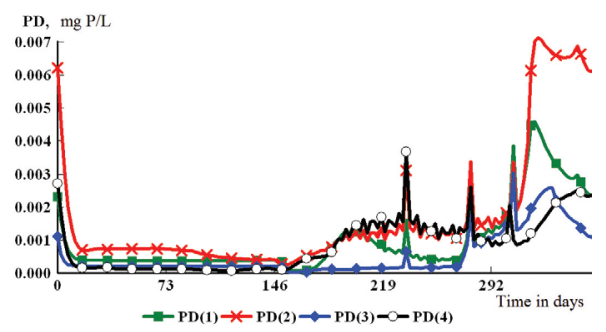

Fig. 3. Dynamics of the concentration of $P$ forms for the second calculated year: DIP (a), DOP (b), PD (c) in the waters of Regions 1-4 (NESS)

The intra-annual changes of the content of $\mathrm{N}$ and $\mathrm{P}$ in dissolved $\left(\mathrm{N}_{\mathrm{dis}}, \mathrm{P}_{\text {dis }}\right)$ and suspended $\left(\mathrm{N}_{\mathrm{par}}, \mathrm{P}_{\mathrm{par}}\right)$ fractions, and also the total content of $\mathrm{N}$ and $\mathrm{P}\left(\mathrm{N}_{\text {tot }}, \mathrm{P}_{\text {tot }}\right)$ in Regions 1-4 are shown in Fig 4. Let us estimate the ranges of variability and rations of these components in different regions of the NESS. The limits of the fluctuations in the waters of the Regions of $1-4$ concentrations of $\mathrm{N}_{\text {dis }}$ are $0.4884-0.6706,0.2737-0.5789$, $0.5146-0.6770$, and $0.2497-0.7568 \mathrm{mg} \mathrm{N} / \mathrm{L}$ (Fig. 4 a), respectively; the concentrations of $\mathrm{N}_{\mathrm{par}}$ - are 0.3-159.5, 2.4-171.7, 0.1-56.6, and 0.5-216.3 $\mu \mathrm{g} \mathrm{N} / \mathrm{L}$ (Fig. $4 \mathrm{c}$ ), and the concentrations of $\mathrm{N}_{\text {tot }}-$ are $0.620-0.679,0.392-0.692,0.530-0.682$, and $0.243-0.932$ $\mathrm{mg} \mathrm{N} / \mathrm{L}$ (Fig. 4 e). In the waters of regions $1-4$, the changes of $\mathrm{P}_{\text {dis }}$ concentrations are 7.7-35.9, 14.4-42.2, 6.5-16.3, and 7.5-47.2 $\mu \mathrm{g}$ P/L (Fig. 4 b), concentrations $\mathrm{P}_{\text {par }}-0.4$ 21.1, 0.6-26.6, 0.1-18.9, and 0.6-23.0 $\mu \mathrm{g} \mathrm{P/L} \mathrm{(Fig.} 4 \mathrm{~d}$ ), the concentrations of $\mathrm{P}_{\text {tot }}$ are 23.3-44.2, 29.5-62.6, 11.2-28.6, and 16.5-70.0 $\mu \mathrm{g}$ P/L (Fig. 4 f). 
(a)

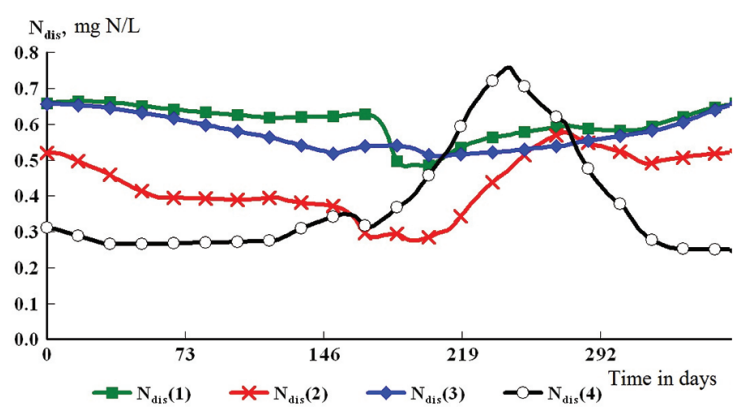

(c)

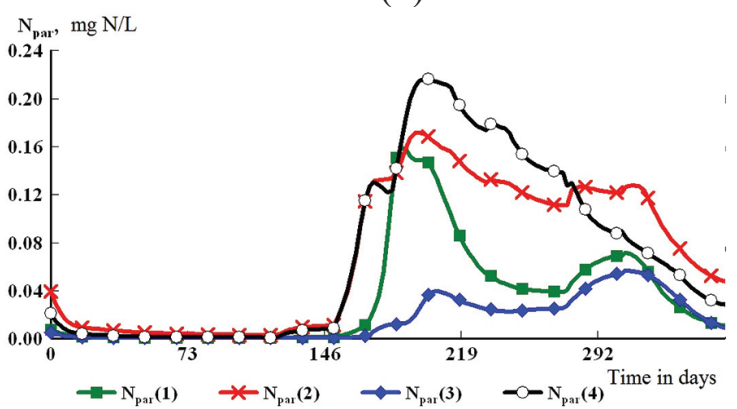

(e)

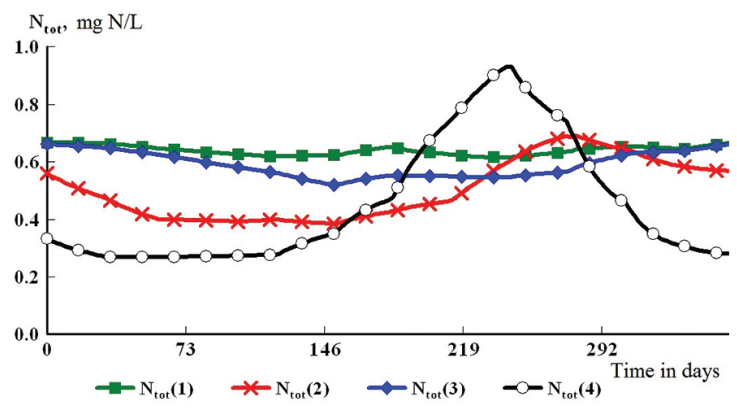

(b)

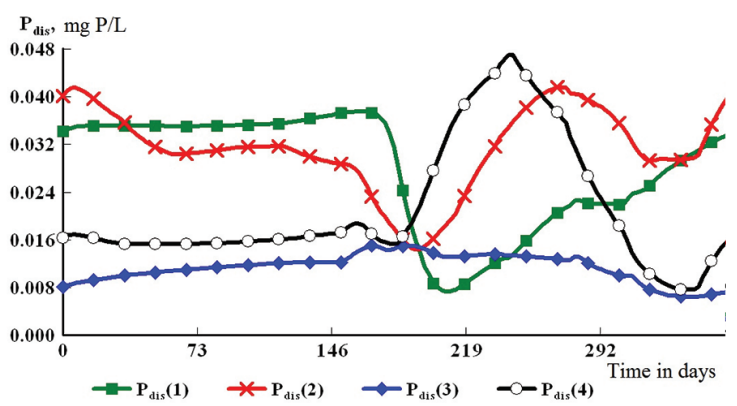

(d)

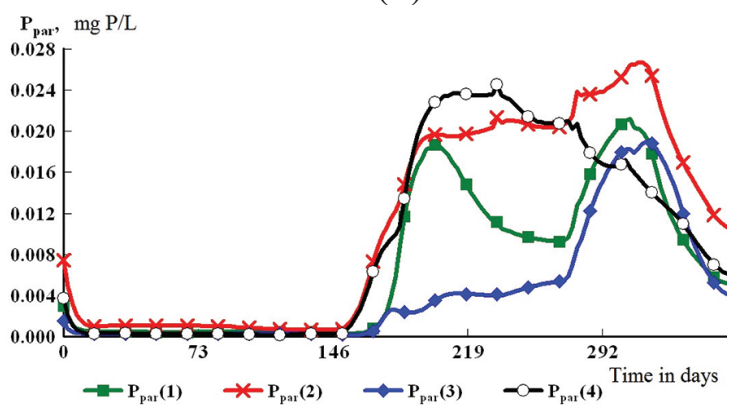

(f)

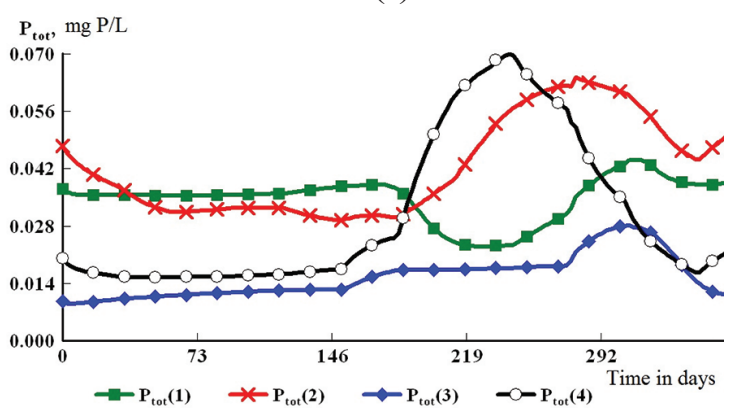

Fig. 4. Dynamics of aggregated concentrations of $\mathrm{N}(\mathrm{a}, \mathrm{c}, \mathrm{e})$ and $\mathrm{P}(\mathrm{b}, \mathrm{d}, \mathrm{f})$ for the second calculated year: $\mathrm{N}_{\text {dis }}(\mathrm{a}), \mathrm{P}_{\text {dis }}(\mathrm{b}), \mathrm{N}_{\mathrm{par}}(\mathrm{c}), \mathrm{P}_{\mathrm{par}}(\mathrm{d}), \mathrm{N}_{\text {tot }}(\mathrm{e}), \mathrm{P}_{\text {tot }}$ (f) in waters of

Regions 1-4 (NESS)

The ratios of $\mathrm{N}_{\text {dis }}: \mathrm{P}_{\text {dis }}$ concentrations in the waters of Regions 1-4 are, respectively (18.7-63.4) : 1, (13.7-19.0) : 1, (41.5-79.2) : 1, and (16-33.3) : $; \mathrm{N}_{\mathrm{par}}: \mathrm{P}_{\mathrm{par}}-(0.8-7.6): 1$, (4-6.5) : 1, (1-3) : 1, and (0.8-9.4) : 1; $\mathrm{N}_{\text {tot }}: \mathrm{P}_{\text {tot }}-(15.4-26.6): 1,(11.1-13.3): 1$, $(23.8-47.3): 1$, and (13.3-14.7) : 1 . Thus, a comparison of the values of the ratios of the components $\mathrm{N}$ and $\mathrm{P}$ shows that:

- in waters of all regions, the range of changes in the proportions of the suspended components $\mathrm{N}_{\text {par }}$ : $\mathrm{P}_{\mathrm{par}}$ is generally lower than the ratio of the concentrations of their dissolved and total components;

- waters of Region 3, into which the river runoff arrives, have smaller ranges of variability in the ratios of the suspended fractions $\mathrm{N}_{\mathrm{par}}$ : $\mathrm{P}_{\text {par }}$ at higher ranges of ratios of their dissolved and total concentrations;

- there are differences in the ratios of the components $\mathrm{N}: \mathrm{P}$ depending on the 
location of the regions: in coastal Regions 1 and 3, on the whole, the ranges of variability of the ratios of dissolved and total $\mathrm{N}: \mathrm{P}$ concentrations are higher than in Regions 2 and 4 remote from the coast.

\section{Analysis of calculated dynamics of organism biomasses in waters of Regions 1-4}

During a year, the changes of BS concentrations in the waters of Regions 1-4 depend on the development of organisms of the lower trophic links - the heterotrophic bacteria $B 1$, different groups of phytoplankton $(F 1, F 2, F 3)$ and zooplanktons $(Z 1, Z 2)$. The features of the development of organisms in different regions of the NESS can be traced from the calculated values of their biomass, specific growth rates $\left(k_{0 \mathrm{i}}\right)$ and bioproduction $\left(\mathrm{BP}_{\mathrm{i}}\right)$. According to the values of biomass, the periods of active development of organisms, associated with the production of organic matter (OM) and BS, are distinguished during a year, the values of the biomass and specific growth rates $k_{0 \mathrm{i}}$ can characterize the environmental conditions for the biomass development. In different regions, the influence of individual factors and the supply of biomass by nutrition substrates may be substantially different. The $\mathrm{BP}_{\mathrm{i}}$ values of each biomass group are calculated on the basis of estimated internal substance fluxes that determine the conditions for the biomass development during their consumption of BS, the release of metabolic products and dead. The maximum values of $k_{0 \mathrm{i}}$ are fixed one or two weeks before the formation of the highest biomass values of considered group of organisms. For areas of the Sakhalin Shelf, an active dynamics of water masses is characterized, and together with internal substance fluxes, these factors significantly affect on the final indicators of the state and development of organisms of the lower trophic links (Pishchal'nik et al., 2014).

In this serie of calculations, the values of the organism biomass are shown in Fig. 5 in the $\mathrm{N}$ units - for heterotrophic bacteria $(B 1 \mathrm{~N})$, three groups of phytoplankton $(F 1 \mathrm{~N}$, $F 2 \mathrm{~N}, F 3 \mathrm{~N}$ ) and two groups of zooplankton (herbivorous $Z 1 \mathrm{~N}$ and predatory $Z 2 \mathrm{~N}$ ). Until mid-May, the biomass of these organisms in the water Region 1-4 of the NESS remains low, the main changes in the biomass values occur from mid-May to the end of a year. In the waters of Region 3, the values of biomass are significantly lower in comparison with other regions. It should be noted that there are fundamental differences in changes of the biomass values in the second half of a year in the waters of coastal Regions 1 and 3 and in Regions 2 and 4 remote from the coast. In dynamics of $B 1 \mathrm{~N}, F 1 \mathrm{~N}$ and $Z 1 \mathrm{~N}$ biomasses, two biomass peaks (spring and autumn) are formed, in the coastal Regions 1 and 3, the minimum values between these two maxima are more expressed. Otherwise, the biomasses of $F 2 \mathrm{~N}, F 3 \mathrm{~N}$ and $Z 2 \mathrm{~N}$ are developing: they have distinct differences in the values of biomass in Regions 1-4: in Regions 1 and 3, the biomasses are lowered, and in Regions 2 and 4, they are increased. It should be noted that the biomass values of $F 1 \mathrm{~N}$ and $F 2 \mathrm{~N}$ are comparable, and in comparison with them, the $F 3 \mathrm{~N}$ biomass values are significantly lower.

Positive values of production $\left(\mathrm{BP}_{\mathrm{i}}\right)$ characterize the conditions of growth of organism biomasses (they occur in the second half of a year). The values of the biomass production are calculated for each region on the basis of the sum of the substance fluxes forming the 
biomass of a particular group of organisms at each time step. It is calculated in two dimensions:

1. Per unit of water volume in the layer under consideration for each month ( $\mathrm{g}$ of Element $/\left(\mathrm{m}^{3} \times\right.$ month $\left.)\right)$.

2. For the whole water volume of the this layer (thousand tons of Element/month). Ranges of production biomass values are shown in Table 6 as their total values for production period.

It should be noted that each group of organisms has characteristic production values and duration of the period with their positive values (Fig. 5; Table 6). Let us estimate the changes of parameters characterizing the development of organism biomasses.

(a)

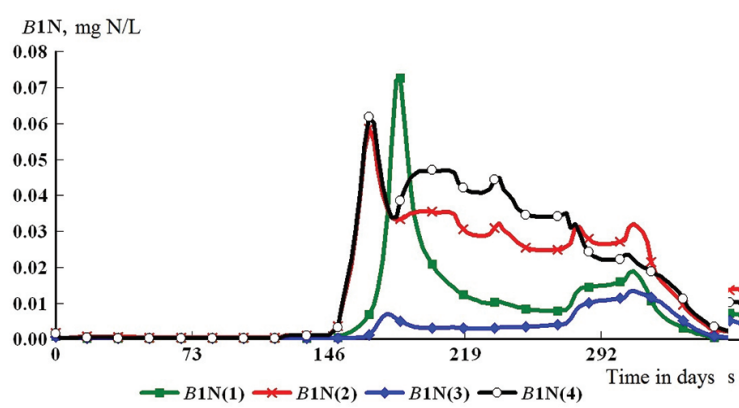

(c)

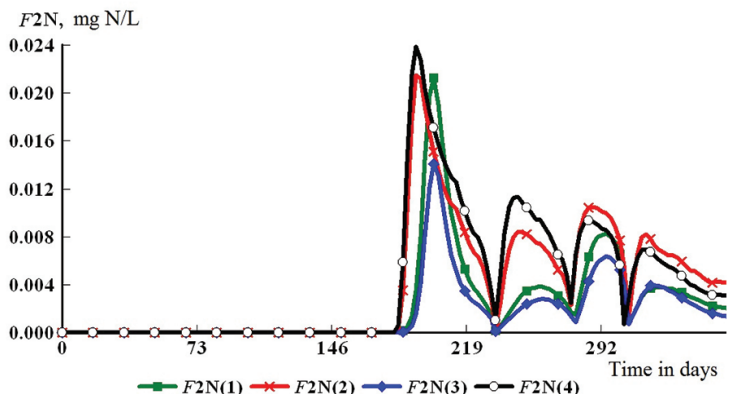

(e)

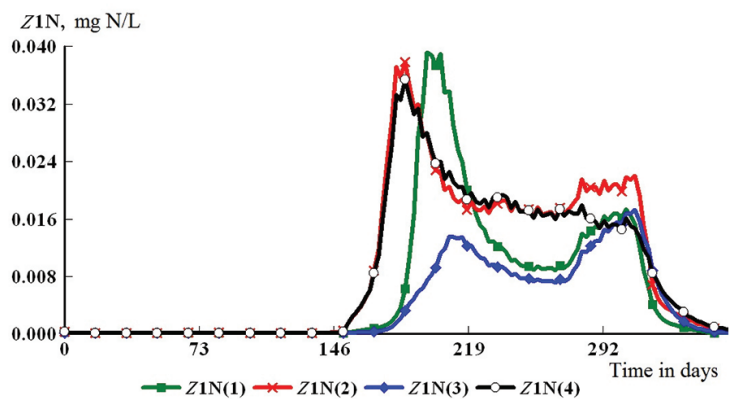

(b)

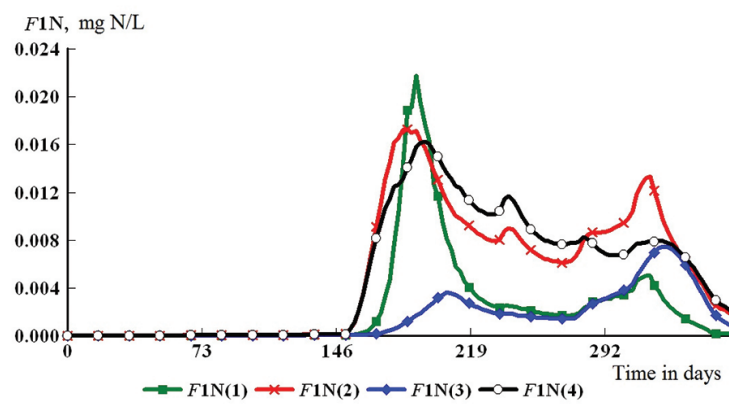

(d)

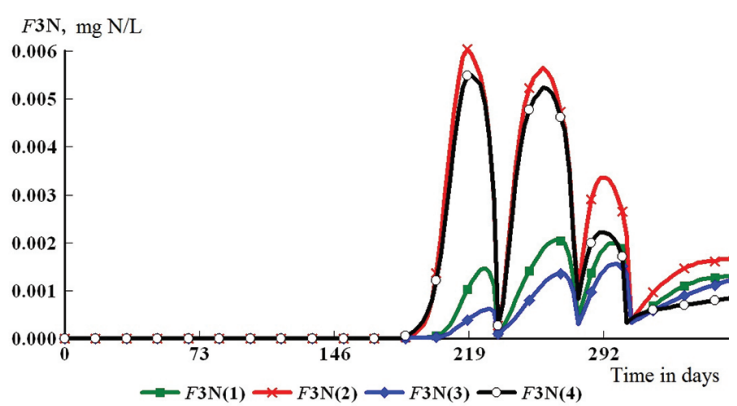

(f)

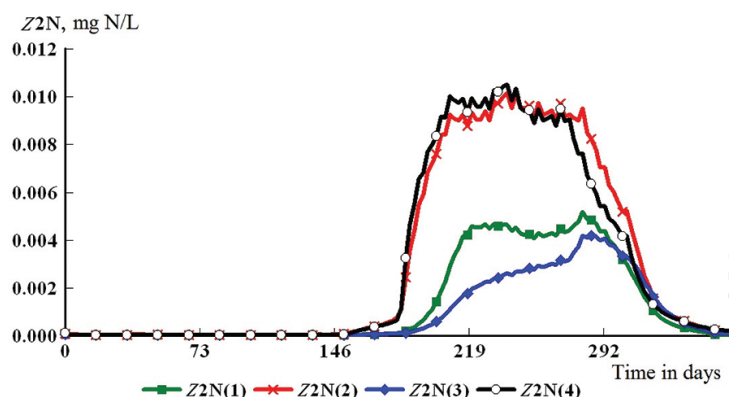

Fig. 5. Dynamics of organism biomasses for the second calculated year: heterotrophic bacteria $B 1 \mathrm{~N}($ a), three phytoplankton groups $-F 1 \mathrm{~N}(\mathrm{~b}), F 2 \mathrm{~N}(\mathrm{c})$, and $F 3 \mathrm{~N}(\mathrm{~d})$, zooplankton: herbivorous, Z1N (e) and predatory, Z2N (f) in waters of Regions 1-4 (NESS) 
Biomass of heterotrophic bacteria $B 1 N$. From the middle of May, there are the differences in development of $B 1 \mathrm{~N}$ biomass in the coastal Regions 1 and 3, as well as in Regions 2 and 4 located further from the coast (Fig. 5 a). In the coastal waters of Region 1, two maxima of the $B 1 \mathrm{~N}$ biomass are created in the second half of a year: the first - in spring $(0.0729 \mathrm{mg} \mathrm{N} / \mathrm{L}$ on the 185 th day) and the second - in autumn $(0.0189 \mathrm{mg} \mathrm{N} / \mathrm{L}$ on the 310th day). The highest values of the specific growth rate of $B 1 \mathrm{~N}$ biomass $\left(k_{0 B 1}\right)$ in spring fall on the 178 th day $\left(0.186\right.$ day $\left.^{-1}\right)$, and in the autumn - by 308th day $\left(0.092\right.$ day $\left.^{-1}\right)$. In the waters of Region 3 in the second half of a year, the $B 1 \mathrm{~N}$ biomass is kept low in comparison with other regions of the NESS: the first small spring maximum here is formed on the 178th day $(0.0070 \mathrm{mg} \mathrm{N} / 1)$ and the second autumn - by 308 day $(0.0130 \mathrm{mg}$ $\mathrm{N} / 1)$. In this region, the highest values of $k_{0 B 1}$ for the formation of the spring and autumn maximums were on 171 st and 278 th days ( 0.297 and 0.178 day $^{-1}$ respectively). By the end of a year, the $B 1 \mathrm{~N}$ biomass in the waters of Regions 1 and 3 decreases to 0.0003 and $0.0002 \mathrm{mg} \mathrm{N} / 1$, respectively.

In Regions 2 and 4, one spring maximum of $B 1 \mathrm{~N}$ biomass is formed (on the 168th day -0.0585 and $0.0618 \mathrm{mg} \mathrm{N} / \mathrm{L}$ respectively) at the highest values of $k_{O B}$ for the $164 \mathrm{th}$ day (0.056 and 0.050 day $^{-1}$, respectively). In the following period (during summer autumn), sufficiently high values of $B 1 \mathrm{~N}$ biomass are maintained in waters of Regions 2 and 4 with a tendency to gradually decrease by the end of a year (respectively to 0.0013 and $0.0011 \mathrm{mg} \mathrm{N} / \mathrm{L}$ ) .

The production period for $B 1 \mathrm{~N}$ bacteria continues in the waters of Regions 1,2 , and 4 from June to November, and in the Region 3 - from June to December (Table 6).

In some months in Regions $1-4$, the ranges of $\mathrm{BP}_{B 1 \mathrm{~N}}$ values, expressed per water volume unit of upper layer, are approximately of the same order (only Region 3 is remarkable for their lower values of $\mathrm{BP}_{B 1 \mathrm{~N}}$ ). The total values of production of $B 1 \mathrm{~N}$ biomass, $\mathrm{BP}_{B 1 \mathrm{~N}}$, for the production period is higher in the water of Regions 2 and 4 (1.8848 and $2.4893 \mathrm{~g} \mathrm{~N} /\left(\mathrm{m}^{3} \times\right.$ month $)$ ), which are far from the coast, in comparison with the coastal Regions 1 and 3 (1.1061 and $0.3124 \mathrm{~g} \mathrm{~N} /\left(\mathrm{m}^{3} \times\right.$ month)). In principle, the same tendencies are preserved even when expressing the values of $\mathrm{BP}_{B 1 \mathrm{~N}}$ for the volume of the entire water layer. However, in this case, the value of $\mathrm{BP}_{B 1 \mathrm{~N}}$ in region of 1 (2002.7 thousand tons $\mathrm{N}$ ) is higher than in the Regions 2-4 (1.149.3, 583.5, and 1613.9 thousand tons $\mathrm{N}$, respectively). When the $\mathrm{BP}_{B 1 \mathrm{~N}}$ is expressed per unit volume of the upper layer water, its maximum values in the waters of Regions 1-4 fall on July, June, October, June $\left(0.5113,0.4614,0.0998,0.8824 \mathrm{~g} \mathrm{~N} /\left(\mathrm{m}^{3} \times\right.\right.$ month $)$, respectively). In the waters of Regions $1-4$, taking into account the entire volumes of water, the largest values of $\mathrm{BP}_{B 1 \mathrm{~N}}$ are registered in July, October, November, and August (correspondingly 735.8, 266.6, 238.7, and 338.1 thousand tons $\mathrm{N} /$ month). These calculated values of $\mathrm{BP}_{B 1 \mathrm{~N}}$ depend directly on the water volumes of the upper layer and indirectly from the concentrations of $\mathrm{BS}$ in the layer, affecting the final values of the production of $\mathrm{BP}_{B 1 \mathrm{~N}}$ biomass (Table 6). 
Table 6. The calculated values of the production (BPi) for organisms in different months and for the whole productive period in Regions 1-4 of NESS (uwl - upper water layer; * for period of positive values of $\mathrm{BPi}$; dash - BPi values are negative)

\begin{tabular}{|c|c|c|c|c|c|c|c|c|c|}
\hline $\begin{array}{l}\text { Volume, } \\
\text { Biota }\end{array}$ & Dimension & VI & VII & VIII & IX & $\mathbf{X}$ & XI & XII & $\sum^{*}$ \\
\hline \multicolumn{10}{|c|}{ Region 1} \\
\hline$V$, uwl & $\mathrm{km}^{3}$ & 959.4 & 1439.1 & 1918.8 & 2398.4 & 2878.1 & 3597.7 & 4796.9 & - \\
\hline$B 1 \mathrm{~N}$ & $\frac{\mathrm{g} \mathrm{N} /\left(\mathrm{m}^{3} \mathrm{mon} .\right)}{\text { thous. } \mathrm{t} \mathrm{N} / \mathrm{mon} .}$ & $\frac{0.2072}{198.78}$ & $\frac{0.5113}{735.81}$ & $\frac{0.0896}{171.92}$ & $\frac{0.0575}{137.91}$ & $\frac{0.1481}{426.25}$ & $\frac{0.0923}{332.07}$ & - & $\frac{1.106}{2002.74}$ \\
\hline$F 1 \mathrm{~N}$ & $\frac{\mathrm{g} \mathrm{N} /\left(\mathrm{m}^{3} \mathrm{mon} .\right)}{\text { thous. } \mathrm{t} \mathrm{N} / \mathrm{mon} .}$ & $\frac{0.0405}{38.86}$ & $\frac{0.2242}{322.65}$ & $\frac{0.0237}{45.48}$ & $\frac{0.0048}{11.51}$ & $\frac{0.0231}{66.48}$ & $\frac{0.0224}{\mathrm{M} 80.59}$ & - & $\frac{0.3387}{565.57}$ \\
\hline$F 2 \mathrm{~N}$ & $\frac{\mathrm{g} \mathrm{N} /\left(\mathrm{m}^{3} \mathrm{mon} .\right)}{\text { thous. } \mathrm{t} \mathrm{N} / \mathrm{mon} \text {. }}$ & - & $\frac{0.1540}{221.62}$ & $\frac{0.0362}{69.46}$ & $\frac{0.0288}{69.07}$ & $\frac{0.0776}{223.41}$ & $\frac{0.0297}{106.85}$ & $\frac{0.0167}{80.11}$ & $\frac{0.3430}{770.52}$ \\
\hline$F 3 \mathrm{~N}$ & $\frac{\mathrm{g} \mathrm{N} /\left(\mathrm{m}^{3} \mathrm{mon} .\right)}{\text { thous. } \mathrm{t} \mathrm{N} / \mathrm{mon} .}$ & - & $\frac{0.0007}{1.01}$ & $\frac{0.0084}{16.12}$ & $\frac{0.0183}{43.89}$ & $\frac{0.0141}{40.58}$ & $\frac{0.0045}{16.19}$ & $\frac{0.0054}{25.90}$ & $\frac{0.0460}{143.69}$ \\
\hline$Z 1 \mathrm{~N}$ & $\frac{\mathrm{g} \mathrm{N} /\left(\mathrm{m}^{3} \mathrm{mon} .\right)}{\text { thous. } \mathrm{t} \mathrm{N} / \mathrm{mon} .}$ & $\frac{0.0010}{0.96}$ & $\frac{0.3985}{573.48}$ & $\frac{0.1644}{315.45}$ & $\frac{0.0728}{174.60}$ & $\frac{0.1525}{438.91}$ & $\frac{0.0531}{191.04}$ & - & $\frac{0.8423}{1694.44}$ \\
\hline$Z 2 \mathrm{~N}$ & $\frac{\mathrm{g} \mathrm{N} /\left(\mathrm{m}^{3} \mathrm{mon} .\right)}{\text { thous. } \mathrm{t} \mathrm{N} / \mathrm{mon} \text {. }}$ & - & $\frac{0.0054}{7.77}$ & $\frac{0.0260}{49.89}$ & $\frac{0.0265}{63.56}$ & $\frac{0.0267}{76.84}$ & $\frac{0.0051}{18.35}$ & - & $\frac{0.0897}{216.41}$ \\
\hline \multicolumn{10}{|c|}{ Region 2} \\
\hline$V$, uwl & $\mathrm{km}^{3}$ & 300.0 & 450.0 & 600.0 & 750.0 & 900.0 & 1125.0 & 1500.0 & - \\
\hline$B 1 \mathrm{~N}$ & $\frac{\mathrm{g} \mathrm{N} /\left(\mathrm{m}^{3} \mathrm{mon} .\right)}{\text { thous. } \mathrm{t} \mathrm{N} / \mathrm{mon} .}$ & $\frac{0.4614}{138.42}$ & $\frac{0.3868}{174.06}$ & $\frac{0.3298}{197.88}$ & $\frac{0.2388}{179.10}$ & $\frac{0.2964}{266.76}$ & $\frac{0.1717}{193.16}$ & - & $\frac{1.8849}{1149.38}$ \\
\hline$F 1 \mathrm{~N}$ & $\frac{\mathrm{g} \mathrm{N} /\left(\mathrm{m}^{3} \mathrm{mon} .\right)}{\text { thous. } \mathrm{t} \mathrm{N} / \mathrm{mon} \text {. }}$ & $\frac{0.1163}{34.89}$ & $\frac{0.1553}{69.89}$ & $\frac{0.0508}{30.48}$ & $\frac{0.0350}{26.25}$ & $\frac{0.0575}{51.75}$ & $\frac{0.0518}{58.28}$ & - & $\frac{0.4667}{271.54}$ \\
\hline$F 2 \mathrm{~N}$ & $\frac{\mathrm{g} \mathrm{N} /\left(\mathrm{m}^{3} \mathrm{mon} .\right)}{\text { thous. } \mathrm{t} \mathrm{N} / \mathrm{mon} \text {. }}$ & - & $\frac{0.2076}{93.42}$ & $\frac{0.0707}{42.42}$ & $\frac{0.0662}{49.65}$ & $\frac{0.1193}{107.37}$ & $\frac{0.0456}{51.30}$ & $\frac{0.0234}{35.10}$ & $\frac{0.5328}{379.26}$ \\
\hline$F 3 \mathrm{~N}$ & $\frac{\mathrm{g} \mathrm{N} /\left(\mathrm{m}^{3} \mathrm{mon} .\right)}{\text { thous. } \mathrm{t} \mathrm{N} / \mathrm{mon} .}$ & - & $\frac{0.0193}{8.69}$ & $\frac{0.0553}{33.18}$ & $\frac{0.0488}{36.60}$ & $\frac{0.0307}{27.63}$ & $\frac{0.0043}{4.84}$ & $\frac{0.0051}{7.65}$ & $\frac{0.1635}{118.59}$ \\
\hline$Z 1 \mathrm{~N}$ & $\frac{\mathrm{g} \mathrm{N} /\left(\mathrm{m}^{3} \mathrm{mon} .\right)}{\text { thous. } \mathrm{t} \mathrm{N} / \mathrm{mon} \text {. }}$ & $\frac{0.1579}{47.37}$ & $\frac{0.4288}{192.96}$ & $\frac{0.1994}{119.64}$ & $\frac{0.1704}{127.80}$ & $\frac{0.2387}{214.83}$ & $\frac{0.0845}{95.06}$ & - & $\frac{1.2797}{797.66}$ \\
\hline$Z 2 \mathrm{~N}$ & $\frac{\mathrm{g} \mathrm{N} /\left(\mathrm{m}^{3} \mathrm{mon} .\right)}{\text { thous. } \mathrm{t} \mathrm{N} / \mathrm{mon} .}$ & $\frac{0.0003}{0.09}$ & $\frac{0.0435}{19.58}$ & $\frac{0.0881}{52.86}$ & $\frac{0.0814}{61.05}$ & $\frac{0.0614}{55.26}$ & $\frac{0.0108}{12.15}$ & - & $\frac{0.2855}{200.99}$ \\
\hline \multicolumn{10}{|c|}{ Region 3} \\
\hline$V$, uwl & $\mathrm{km}^{3}$ & 700.0 & 1050.0 & 1400.0 & 1750.0 & 2100.0 & 2625.0 & 3500.0 & - \\
\hline$B 1 \mathrm{~N}$ & $\frac{\mathrm{g} \mathrm{N} /\left(\mathrm{m}^{3} \mathrm{mon} .\right)}{\text { thous. } \mathrm{t} \mathrm{N} / \mathrm{mon} .}$ & $\frac{0.0451}{31.57}$ & $\frac{0.0326}{34.23}$ & $\frac{0.0215}{30.10}$ & $\frac{0.0225}{39.38}$ & $\frac{0.0998}{209.58}$ & $\frac{0.0909}{238.61}$ & - & $\frac{0.3124}{583.47}$ \\
\hline$F 1 \mathrm{~N}$ & $\frac{\mathrm{g} \mathrm{N} /\left(\mathrm{m}^{3} \mathrm{mon} .\right)}{\text { thous. } \mathrm{t} \mathrm{N} / \mathrm{mon} .}$ & $\frac{0.0037}{0.03}$ & $\frac{0.0388}{40.74}$ & $\frac{0.0109}{15.26}$ & $\frac{0.0102}{17.85}$ & $\frac{0.0309}{64.89}$ & $\frac{0.0472}{123.90}$ & $\frac{0.0108}{37.80}$ & $\frac{0.1525}{300.47}$ \\
\hline$F 2 \mathrm{~N}$ & $\frac{\mathrm{g} \mathrm{N} /\left(\mathrm{m}^{3} \mathrm{mon} .\right)}{\text { thous. } \mathrm{t} \mathrm{N} / \mathrm{mon} \text {. }}$ & - & $\frac{0.0892}{93.66}$ & $\frac{0.0194}{27.16}$ & $\frac{0.0206}{36.05}$ & $\frac{0.0532}{111.72}$ & $\frac{0.0352}{92.40}$ & $\frac{0.0155}{54.25}$ & $\frac{0.2331}{415.24}$ \\
\hline$F 3 \mathrm{~N}$ & $\frac{\mathrm{g} \mathrm{N} /\left(\mathrm{m}^{3} \mathrm{mon} .\right)}{\text { thous. } \mathrm{t} \mathrm{N} / \mathrm{mon} .}$ & - & $\frac{0.0003}{0.32}$ & $\frac{0.0039}{5.46}$ & $\frac{0.0065}{11.38}$ & $\frac{0.0095}{19.95}$ & $\frac{0.0040}{10.50}$ & $\frac{0.0051}{17.85}$ & $\frac{0.0293}{65.46}$ \\
\hline$Z 1 \mathrm{~N}$ & $\frac{\mathrm{g} \mathrm{N} /\left(\mathrm{m}^{3} \mathrm{mon} .\right)}{\text { thous. } \mathrm{t} \mathrm{N} / \mathrm{mon} .}$ & $\frac{0.0015}{1.05}$ & $\frac{0.1040}{109.20}$ & $\frac{0.0995}{139.30}$ & $\frac{0.0539}{94.33}$ & $\frac{0.1237}{259.77}$ & $\frac{0.0832}{218.40}$ & $\frac{0.0003}{1.05}$ & $\frac{0.4661}{823.10}$ \\
\hline$Z 2 \mathrm{~N}$ & $\frac{\mathrm{g} \mathrm{N} /\left(\mathrm{m}^{3} \mathrm{mon} .\right)}{\text { thous. } \mathrm{t} \mathrm{N} / \mathrm{mon} .}$ & - & $\frac{0.0031}{3.26}$ & $\frac{0.0146}{20.44}$ & $\frac{0.0155}{27.12}$ & $\frac{0.0218}{45.78}$ & $\frac{0.0078}{20.48}$ & $\frac{0.0006}{2.10}$ & $\frac{0.0634}{119.19}$ \\
\hline \multicolumn{10}{|c|}{ Region 4} \\
\hline$V$, uwl & $\mathrm{km}^{3}$ & 375.3 & 563.0 & 750.7 & 938.4 & 1126.0 & 1407.5 & 1876.7 & - \\
\hline$B 1 \mathrm{~N}$ & $\frac{\mathrm{g} \mathrm{N} /\left(\mathrm{m}^{3} \mathrm{mon} .\right)}{\text { thous. t N/mon. }}$ & $\frac{0.8824}{331.16}$ & $\frac{0.5721}{322.09}$ & $\frac{0.4504}{338.12}$ & $\frac{0.3081}{289.12}$ & $\frac{0.1970}{221.82}$ & $\frac{0.0793}{111.62}$ & - & $\frac{2.4893}{1613.93}$ \\
\hline$F 1 \mathrm{~N}$ & $\frac{\mathrm{g} \mathrm{N} /\left(\mathrm{m}^{3} \mathrm{mon} .\right)}{\text { thous. } \mathrm{t} \mathrm{N} / \mathrm{mon} .}$ & $\frac{0.2718}{102.01}$ & $\frac{0.2906}{163.61}$ & $\frac{0.0990}{74.32}$ & $\frac{0.0584}{54.80}$ & $\frac{0.0501}{56.41}$ & $\frac{0.0355}{49.97}$ & $\frac{0.0010}{1.88}$ & $\frac{0.8064}{503.00}$ \\
\hline$F 2 \mathrm{~N}$ & $\frac{\mathrm{g} \mathrm{N} /\left(\mathrm{m}^{3} \mathrm{mon} .\right)}{\text { thous. } \mathrm{t} \mathrm{N} / \mathrm{mon} .}$ & - & $\frac{0.2560}{144.13}$ & $\frac{0.0928}{69.67}$ & $\frac{0.0781}{73.29}$ & $\frac{0.0677}{76.23}$ & $\frac{0.0311}{43.77}$ & $\frac{0.0129}{24.21}$ & $\frac{0.5386}{431.30}$ \\
\hline
\end{tabular}




\begin{tabular}{|c|c|c|c|c|c|c|c|c|c|}
\hline F3N & $\frac{\mathrm{g} \mathrm{N} /\left(\mathrm{m}^{3} \mathrm{mon} .\right)}{\text { thous. t N/mon. }}$ & - & $\frac{0.0143}{8.05}$ & $\frac{0.0497}{37.31}$ & $\frac{0.0482}{45.23}$ & $\frac{0.0222}{25.00}$ & $\frac{0.0026}{3.66}$ & $\frac{0.0035}{6.57}$ & $\frac{0.1405}{125.82}$ \\
\hline$Z 1 \mathrm{~N}$ & $\frac{\mathrm{g} \mathrm{N} /\left(\mathrm{m}^{3} \mathrm{mon} .\right)}{\text { thous. t N/mon. }}$ & $\frac{0.2653}{99.57}$ & $\frac{0.6595}{371.30}$ & $\frac{0.2555}{191.80}$ & $\frac{0.1889}{177.27}$ & $\frac{0.1691}{190.41}$ & $\frac{0.0632}{88.95}$ & - & $\frac{1.6015}{1119.30}$ \\
\hline$Z 2 \mathrm{~N}$ & $\frac{\left.\mathrm{g} \mathrm{N} / \mathrm{m}^{3} \mathrm{mon} .\right)}{\text { thous. t N/mon. }}$ & $\frac{0.0008}{0.30}$ & $\frac{0.0499}{28.09}$ & $\frac{0.0867}{65.09}$ & $\frac{0.0778}{73.01}$ & $\frac{0.0459}{51.68}$ & $\frac{0.0076}{10.70}$ & - & $\frac{0.2687}{228.87}$ \\
\hline
\end{tabular}

The biomass of the first phytoplankton group, $\boldsymbol{F} \mathbf{1 N}$, develops with the formation of two maxima (in spring, and in autumn). However, in some cases, the severity of seasonal $F 1 \mathrm{~N}$ maximums in regions are different. For example, in Region 3, the spring $F 1 \mathrm{~N}$ maximum is smoothed out, and in the Region 4, their autumnal maximum is smoothed (Fig. 5 b). In Regions $1-4$, of the spring maximum of the $F 1 \mathrm{~N}$ biomass fall respectively on the 190th, 185th, 207th, and 195th days $(0.0219,0.0173,0.0036$, and $0.0163 \mathrm{mg} \mathrm{N} / \mathrm{L})$. In Regions $1-4$, the largest values of $k_{0 F 1}$ forming spring $F 1 \mathrm{~N}$ peaks are respectively, $0.385,0.127,0.166$, and 0.125 day $^{-1}$ (and these are found on 183rd, 178th, 195th, and 183 rd days.

The pronounced minima of the $F 1 \mathrm{~N}$ biomass between the spring and autumn peaks in the waters of Regions 1-3 are registered for the 269-272nd days $(0.0016,0.0061$, and $0.0014 \mathrm{mg} \mathrm{N} / \mathrm{L}$, respectively), and in waters of Region 4 - in the above-mentioned period of the $F 1 \mathrm{~N}$ minimum is formed later - on the 300th day $(0.0067 \mathrm{mg} \mathrm{N} / \mathrm{L})$.

The autumn $F 1 \mathrm{~N}$ maximum was observed in Regions $1-2$ at 317 th day $(0.0050$ and $0.0133 \mathrm{mg} \mathrm{N} / \mathrm{L}$ ), and in Regions $3-4-$ at $323 \mathrm{nd}$ day (0.0074 and $0.0079 \mathrm{mg} \mathrm{N} / \mathrm{L})$. The highest $k_{0 F 1}$ values in the Regions $1-4$ forming the autumn $F 1 \mathrm{~N}$ peaks fall on the 310 th day $\left(0.319,0.100,0.156\right.$, and 0.091 day $^{-1}$, respectively). By the end of a year, the $F 1 \mathrm{~N}$ values decrease to $0.0001-0.0005$ and $0.0013-0.0012 \mathrm{mg} \mathrm{N} / \mathrm{L}$ respectively in the coastal Regions 1 and 3 and in Regions 2 and 4 located further from the coast.

In Regions 1-2 and 3-4, the formation of $F 1 \mathrm{~N}$ production, $\mathrm{BP}_{F 1 \mathrm{~N}}$, occurs respectively in periods of June-November and June-December. The ranges of $\mathrm{BP}_{\mathrm{F} 1 \mathrm{~N}}$ changes for the production period in Regions $1-2$ are $0.0048-0.2242$ and $0.0350-0.1553 \mathrm{~g} \mathrm{~N} /\left(\mathrm{m}^{3} \times\right.$ month $)$ (at the total values of 0.3387 and 0.4667 grams N/m $\left.{ }^{3}\right)$, and in Regions 3 and $4-(0.0037-$ 0.0472 and $0.0010-0.2906 \mathrm{~g} \mathrm{~N} /\left(\mathrm{m}^{3} \times\right.$ month) (at the total of 0.1525 and $\left.0.8064 \mathrm{~g} \mathrm{~N} / \mathrm{m}^{3}\right)$ ). The $\mathrm{BP}_{F 1 \mathrm{~N}}$ values based on the water volume of the upper layer in the coastal part of the sea are higher in Region 1 (11.5-322.7 thousand tons N/month (the total amount is 565.6 thousand tons $\mathrm{N})$ than in the Region $3(0.03-123.9,303.5)$, and in regions remote from the coast, it is higher in Region 4 (1.9-163.6, 503.0) than in Region 2 (26.3-69.9, 271.5 thousand tons $\mathrm{N} /$ month). In Regions 1,2 and 4, the $\mathrm{BP}_{F 1 \mathrm{~N}}$ highest values on the unit water volume of the upper layer were recorded in July $(0.2242,0.1553$, and $0.2906 \mathrm{~g} \mathrm{~N} /$ ( $\mathrm{m}^{3} \times$ month), and in Region 3 - in November (0.0472 grams N/( $\mathrm{m}^{3} \times$ month)).

In calculations of the $\mathrm{BP}_{F 1 \mathrm{~N}}$ values for the volume of the whole layer, in Regions 1, 2 and 4 in July, the largest values are 322.7, 69.9, and 163.6 thousand tons $\mathrm{N} /\left(\mathrm{m}^{3} \times\right.$ month $)$, and in Region 3 - in November (123.8 thousand tons $\mathrm{N} /\left(\mathrm{m}^{3} \times\right.$ month $\left.)\right)$. The total $\mathrm{BP}_{\mathrm{F} 1 \mathrm{~N}}$ values for the production period in the waters of Regions $1-4$ are 565.6, 271.5, 300.5, and 503.0 thousand tons of $\mathrm{N}$ (Table 6). 
The phytoplankton biomasses of the second and third groups, $F 2 \mathrm{~N}$ and $F 3 \mathrm{~N}$, in the second half of a year, develop similarly to each region with rather rapid alternations of intermediate biomass maxima and minima (Fig. 5 c, d). Generally, the formation of $F 2 \mathrm{~N}$ maxima occurs earlier than the maximum of $F 3 \mathrm{~N}$. A sharp change in the extremes of the $F 2 \mathrm{~N}$ and $F 3 \mathrm{~N}$ biomasses is caused by the conditions of water exchange between the regions in the period 182-365th days. The maximums are formed simultaneously - first in the Regions 2 and 4 located further from the coast, and then in the coastal Regions 1 and 3.

The first $F 2 \mathrm{~N}$ maximum in Regions 2 and 4 is formed on the 192th day (0.0214 and $0.0237 \mathrm{mg} \mathrm{N} / \mathrm{L}$ ) with the largest values of $k_{0 F 2} 0.498-0.564$ and $0.533-0.540$ day $^{-1}$ fixed in these regions on the 178-183th days. In the waters of Regions 1 and 3, the first maximum of $F 2 \mathrm{~N}$ biomass falls on the $202 \mathrm{nd}$ day $(0.0213$ and $0.0139 \mathrm{mg} \mathrm{N} / \mathrm{L}$ at the highest values of $k_{0 F 2} 0.427-0.436$ and $0.516-0.527$ day $^{-1}$ on the $190-192$ th days). Then, at the 236 th day, simultaneous formation of the first intermediate minimum $F 2 \mathrm{~N}(0.0001-0.0010 \mathrm{mg} \mathrm{N} / \mathrm{L})$ in Regions 1-4 was noted (Fig. 5 c).

The second maximum of $F 2 \mathrm{~N}(0.0084$ and $0.0113 \mathrm{mg} \mathrm{N} / \mathrm{L})$ in Regions 2 and 4 was marked on the 248th day at the corresponding maximum values of $k_{0 F 2} 0.300$ and 0.230 day $^{-1}$ (at the 238th day). In the waters of Regions 1 and 3, the second maximum of $F 2 \mathrm{~N}$ falls on the 260th day $(0.0038$ and $0.0028 \mathrm{mg} \mathrm{N} / 1)$, and the largest values of $k_{0 F 2}$ in these regions $\left(0.389\right.$ and 0.330 day $\left.^{-1}\right)$ were also noted on the 238 th day. The second $F 2 \mathrm{~N}$ minimum $(0.0008-0.0024 \mathrm{mg} \mathrm{N} / \mathrm{L})$ is formed on the 277 th day simultaneously in Regions $1-4$ (Fig. 5 c).

The third maximum of $F 2 \mathrm{~N}$ in Regions 2 and 4 (0.0104 and $0.0093 \mathrm{mg} \mathrm{N} / \mathrm{L})$ falls on the 288th day and the largest values of $k_{0 \mathrm{~F} 2}\left(0.278\right.$ and 0.230 day $\left.^{-1}\right)-$ on the 276th day. In Regions 1 and 3, the values of the third F2N maximum ( 0.0082 and $0.0063 \mathrm{mg} \mathrm{N} / \mathrm{L})$ were recorded on the 296th day, and the largest values of $k_{0 \mathrm{~F} 2}\left(0.377\right.$ and 0.416 day $\left.^{-1}\right)-$ on the 278th day. The third minimum of $F 2 \mathrm{~N}(0.7-1.2 \mu \mathrm{g} \mathrm{N} / \mathrm{L})$ was recorded on the 306th day (Fig. 5 c).

In Regions 2 and 4, the fourth $F 2 \mathrm{~N}$ maximum of ( 0.0082 and $0.0069 \mathrm{mg} \mathrm{N} / \mathrm{L})$ occurs on the 317 th day, and they are formed at the highest values of $k_{0 F 2}\left(0.383\right.$ and 0.430 day $\left.^{-1}\right)$ by the 305-308th days. In the waters of Regions 1 and 3, the fourth $F 2 \mathrm{~N}$ maximum $(0.0038$ and $0.0039 \mathrm{mg} \mathrm{N} / \mathrm{L})$ are fixed for the 324th day, and the largest values of $k_{0 \mathrm{~F} 2}(0.322$ and 0.383 day $^{-1}$ ) - on the 308th day. By the end of a year, the $F 2 \mathrm{~N}$ biomass values in Regions $1-4$ decrease to $0.0019,0.0040,0.0013,0.0029 \mathrm{mg} \mathrm{N} / \mathrm{L}$ respectively (Fig. $5 \mathrm{c}$ ).

In the waters of Regions $1-2$ and 3-4, the production values of $F 2 \mathrm{~N}, \mathrm{BP}_{F 2 \mathrm{~N}}$, are formed respectively in July-December and June-December. The fluctuation limits of the $\mathrm{BP}_{F 2 \mathrm{~N}}$ values for the production period in the Regions $1-2$ are $0.0167-0.1540$ and $0.0234-0.2076 \mathrm{~g} \mathrm{~N} /\left(\mathrm{m}^{3} \times\right.$ month) respectively (at the total values -0.3430 and 0.5328 $\left.\mathrm{g} \mathrm{N} / \mathrm{m}^{3}\right)$, and in regions 3 and $4-\left(0.0155-0.0892\right.$ and $0.0311-0.2560 \mathrm{~g} \mathrm{~N} /\left(\mathrm{m}^{3} \times\right.$ month $)$ at total values -0.2331 and 0.5398 grams $\mathrm{N} / \mathrm{m}^{3}$ ). The values of $\mathrm{BP}_{F 2 \mathrm{~N}}$ in terms of the volume of the upper layer water in the coastal part of the sea are higher in the Region 1 (69.1-223.4 thousand tons N/month with the total value of 770.5 thousand tons $N$ ) than in the Region 3 (27.2-111.7, 415.2 thousand tons N), and in Regions 2 and 4, these values 
are higher: in the Region $4-24.2-144.1$ thousand tons N/month (with the total value of 431.3 thousand tons N) and in the Region 2 - (35.1-107.4, 379.3 thousand tons N). In Regions $1-4$, the largest values of $\mathrm{BP}_{\mathrm{F} 2 \mathrm{~N}}$ were recorded in July $(0.1540,0.2076,0.0892$, and 0.2560 grams $\mathrm{N} /\left(\mathrm{m}^{3} \times\right.$ month $\left.)\right)$ per unit volume of the upper layer. When calculating the $F 2 \mathrm{~N}$ production values for the entire layer, the increased values of $\mathrm{BP}_{F 2 \mathrm{~N}}$ in the Regions 1-4 are for July and October (221.6 and 223.4, 93.4 and 107.4, 93.7 and 111.7, and 144.1 and 76.2 thousand tons $\mathrm{N} /$ month). The total values of $\mathrm{BP}_{F 2 \mathrm{~N}}$ for the production season in the waters of Regions $1-4$ are $770.5,379.3,415.2$, and 431.3 thousand tons $\mathrm{N}$ (Table 6).

The development of $F 3 \mathrm{~N}$ biomass differs from $F 2 \mathrm{~N}$ in the values and dates in the formation of intermediate peaks (the formation of $F 3 \mathrm{~N}$ maxima occurs later and their values are lower). There are also similar features in the dynamics of biomasses $F 3 \mathrm{~N}$ and F2N: their peaks in time are earlier formed in the waters of Regions 2 and 4 (remoted from the coast) than in coastal Regions 1 and 3 (Fig. 5 c, d).

In Regions 2 and 4, the first intermediate maximum of $F 3 \mathrm{~N}$ biomass $\left(6.03 \times 10^{-3}\right.$ and $5.47 \times 10^{-3} \mathrm{mg} \mathrm{N} / \mathrm{L}$ respectively) is formed on the 219 th day at the largest values of $k_{0 F 3}$ (0.277 and 0.213 day $^{-1}$ at 201st day). In Regions 1 and 3, the first intermediate maximum of $F 3 \mathrm{~N}\left(1.46 \times 10^{-3}\right.$ and $\left.6.02 \times 10^{-3} \mathrm{mg} \mathrm{N} / \mathrm{L}\right)$ is formed on the 228th day with the largest values of $k_{0 F 3}\left(0.148\right.$ and 0.141 day $\left.^{-1}\right)$ on the 214 th day. Further quickly enough, the $F 3 \mathrm{~N}$ values in all regions are reduced to the first intermediate minimum $\left(9.90 \times 10^{-5}-2.63 \times 10^{-4}\right.$ $\mathrm{mg} \mathrm{N} / \mathrm{L}$ ).

The second maximum of F3N in Regions 2 and $4\left(5.64 \times 10^{-3}\right.$ and $5.23 \times 10^{-3} \mathrm{mg}$ $\mathrm{N} / \mathrm{L})$ is fixed on the 260th day with the corresponding largest values of $k_{0 F 3}(0.436$ and 0.383 day $\left.^{-1}\right)$, which fall on the 238th day. In the Regions 1 and 3, the second maximum of $F 3 \mathrm{~N}\left(2.03 \times 10^{-3}\right.$ and $\left.1.34 \times 10^{-3} \mathrm{mg} \mathrm{N} / \mathrm{L}\right)$ was recorded on the 269 th day, and the largest values of $k_{0 F 3}\left(0.265\right.$ and 0.233 day $\left.^{-1}\right)$ were also on the 238 th day. However, already on the 279 th day, the $F 3 \mathrm{~N}$ biomass in waters of all regions is reduced to its second minimum, the values of which fall within the range (2.89-9.40) $\times 10^{-4} \mathrm{mg} \mathrm{N} / \mathrm{L}$.

The third intermediate maximum of $F 3 \mathrm{~N}$ in Regions 2 and $4\left(3.34 \times 10^{-3}\right.$ and $\left.2.20 \times 10^{-3} \mathrm{mg} \mathrm{N} / \mathrm{L}\right)$ falls on $293 \mathrm{nd}$ day, and the maximum values of $k_{0 F 3}(0.347$ and 0.300 day $\left.^{-1}\right)$ on the 279 th day. In Regions 1 and 3, the third maximum of $F 3 \mathrm{~N}\left(1.99 \times 10^{-3}\right.$ and $\left.1.55 \times 10^{-3} \mathrm{mg} \mathrm{N} / \mathrm{L}\right)$ was recorded on the 298 th day at the highest values $k_{0 F 3}(0.275$ and 0.280 day $^{-1}$ ) which also falls on the 279th day. Further by the 308th day, the third intermediate minimum of the $F 3 \mathrm{~N}$ biomass is reached, and their values in all regions lie within the limits $(3.16-4.10) \times 10^{-4} \mathrm{mg} \mathrm{N} / \mathrm{L}$. In Regions $1-4$ by the end of a year, $F 3 \mathrm{~N}$ biomass values increase to $1.30 \times 10^{-3}, 1.67 \times 10^{-3}, 1.25 \times 10^{-3}, 8.57 \times 10^{-4} \mathrm{mg} \mathrm{N} / \mathrm{L}$ respectively (Fig. 5d).

It should be noted that each regular maximum of $F 3 \mathrm{~N}$ biomass in the waters of Regions 2 and 4, removed from the coast, becomes lower, and in coastal Regions 1 and 3 , on the contrary, higher than the corresponding previous $F 3 \mathrm{~N}$ maximum. There is also a regularity for the following minimum $F 3 \mathrm{~N}$ biomasses: as a whole, each subsequent minimum of $F 3 \mathrm{~N}$ biomass in each region is higher than the it's fixed previous minimum (Fig 5 d). 
In the waters of Regions $1-4$, the production of $\mathrm{BP}_{F 3 \mathrm{~N}}$ is formed in July-December. The ranges of changes in the $\mathrm{BP}_{F 3 \mathrm{~N}}$ values for the production period in Regions 1-4 are 0.0007-0.0183, 0.0043-0.0553, 0.0003-0.0095, and 0.0026-0.0497 g N/(m $\mathrm{m}^{3} \times$ month) (at total values of $0.0460,0.1635,0.0293$, and $\left.0.1405 \mathrm{~g} \mathrm{~N} / \mathrm{m}^{3}\right)$. The values of $\mathrm{BP}_{F 3 \mathrm{~N}}$ in terms of the volume of the upper layer water in the coastal part of the sea are higher in the Region 1 (1.0-43.9 thousand tons N/month with a total of 143.7 thousand tons $\mathrm{N}$ ) than in the Region $3(0.3-19.9,85.5)$, and in regions far from the coast - these values are higher in the Region $4(3.7-45.2,125.8)$ than in the Region $2(4.8-36.6$ thousand tons N/month and total 118.6 thousand tons $\mathrm{N}$ ).

The largest values of $\mathrm{BP}_{F 3 \mathrm{~N}}$ in coastal Regions 1 and 3 were recorded in September and October (respectively 0.0183 and $0.0095 \mathrm{~g} \mathrm{~N} /\left(\mathrm{m}^{3} \times\right.$ month)), and in Regions 2 and 4, remoted from the coast - in August (0.0553 and $0.0497 \mathrm{~g} \mathrm{~N} /\left(\mathrm{m}^{3} \times \mathrm{month}\right)$ ). When calculating the values of $F 3 \mathrm{~N}$ production for the entire layer, the higher values of $\mathrm{BP}_{F 2 \mathrm{~N}}$ in Regions 1, 2, and 4 occur in September (correspondingly 43.9, 36.6, and 45.2 thousand tons N/month), and in the Region 3 - on October (19.9 thousand tons N/month). The total values of $\mathrm{BP}_{F 3 \mathrm{~N}}$ in the waters of Regions 1-4 during the production season are 143.7, $118.6,65.5$, and 125.8 thousand tons $\mathrm{N}$, respectively (Table 6).

The biomass of the herbivorous (Z1N) and predatory (Z2N) zooplankton. There are significant differences in the zooplankton dynamics of the NESS waters. In each region in the second half of a year, two intermediate maximums of $Z 1 \mathrm{~N}$ biomass are created, while only one enough long period of increased values of $Z 2 \mathrm{~N}$ biomass is found in summer-autumn with its small fluctuations (some exception is for Region 3 in which a slower development of $Z 2 \mathrm{~N}$ biomass is noted as a whole) (Fig. 5 e, f).

In remoted from the coast Regions 2 and 4, the development of $Z 1 \mathrm{~N}$ biomass begins earlier than in coastal Regions 1 and 3. The first maximum of $Z 1 \mathrm{~N}$ biomass in Regions 2 and $4\left(3.78 \times 10^{-2}\right.$ and $\left.3.54 \times 10^{-2} \mathrm{mg} \mathrm{N} / \mathrm{L}\right)$ was recorded in the 185 th day at largest values of $k_{0 Z 1}\left(0.551\right.$ and 0.528 day $\left.^{-1}\right)$ at $173 \mathrm{rd}$ day. The first maximum of $Z 1 \mathrm{~N}$ biomass in the Region $1\left(3.94 \times 10^{-2} \mathrm{mg} \mathrm{N} / \mathrm{L}\right)$ falls on the 197 th day, and in the region 3 $\left(1.35 \times 10^{-2} \mathrm{mg} \mathrm{N} / \mathrm{L}\right)$ - by the 209th day at the largest $k_{0 Z 1}\left(0.605\right.$ and 0.411 day $\left.^{-1}\right)$ on the 185 th day. The intermediate $Z 1 \mathrm{~N}$ biomass minimum in all regions, within the limits of $(0.70-1.60) \times 10^{-2} \mathrm{mg} \mathrm{N} / \mathrm{L}$, is fixed on the 267 th day (Fig. 5 e).

The second maximum of $Z 1 \mathrm{~N}$ biomass in the waters of regions $1-4$ is $1.73 \times 10^{-2}$, $2.20 \times 10^{-2}, 1.72 \times 10^{-2}$, and $1.61 \times 10^{-2} \mathrm{mg} \mathrm{N} / \mathrm{L}$ respectively, and is formed on the $305-$ 310 th days at the highest values $k_{0 Z 1}\left(0.306-0.332\right.$ day $\left.^{-1}\right)$ fixed on the 298th day. By the end of a year, the values of Z1N biomass in waters of Regions $1-4$ are reduced to $7.80 \times 10^{-5}, 2.45 \times 10^{-4}, 6.40 \times 10^{-5}$, and $2.44 \times 10^{-4} \mathrm{mg} \mathrm{N} / \mathrm{L}$ respectively (Fig. $5 \mathrm{e}$ ).

Formation of $Z 1 \mathrm{~N}$ productions in waters of Regions 1, 2 and 4 is carried out in June-November, and in Region 3 - in June-December. The range of changes in the values of $\mathrm{BP}_{\mathrm{Z1N}}$ for Regions $1-4$ is $0.0010-0.3985,0.0845-0.4288,0.0003-0.1237$, and $0.0632-0.6595 \mathrm{~g} \mathrm{~N} /\left(\mathrm{m}^{3} \times\right.$ month $)$, respectively, with their total values of $0.8423,1.2797$, 0.4661 , and 1.6015 thousand tons $\mathrm{N}$. When expressing the $Z 1 \mathrm{~N}$ production on the volume of the upper layer water, the ranges of values of $\mathrm{BP}_{Z 1 \mathrm{~N}}$ for Regions 1-4 are 1.0-573.4, 
47.4-214.8, 1.0-259.8, and 89.0-371.3 thousand tons $\mathrm{N} /$ month with the total values for the entire production period respectively, 1694.5, 797.7, 823.1, and 1119.3 thousand tons $\mathrm{N}$. The highest values of $\mathrm{BP}_{Z 1 \mathrm{~N}}$ in the waters of Regions 1,2 , and 4 fall in July $(0.3985$, 0.4288 , and $0.6595 \mathrm{~g} \mathrm{~N} /\left(\mathrm{m}^{3} \times\right.$ month $)$ or $573.5,193.0$, and 371.3 thousand tons $\mathrm{N} /$ month), and in the Region of 3 - in October $\left(0.1237 \mathrm{~g} \mathrm{~N} /\left(\mathrm{m}^{3} \times\right.\right.$ month $)$ or 259.8 thousand tons $\mathrm{N} /$ month).

As in the case of $Z 1 \mathrm{~N}$ biomass, the development of $Z 2 \mathrm{~N}$ biomass begins earlier in Regions 2 and 4 remoted from the coast, and the first maximum of $Z 2 \mathrm{~N}$ biomass falls in these regions respectively on the 209th and 204th days $\left(9.22 \times 10^{-3}\right.$ and $9.14 \times 10^{-3} \mathrm{mg}$ $\mathrm{N} / \mathrm{L}$ ) with the largest values of $k_{0 z 2} 0.179$ and 0.118 day $^{-1}$ (on the 197th day). The second maximum of $Z 2 \mathrm{~N}$ in these regions is formed respectively on the 281th and 274th days $\left(9.48 \times 10^{-3}\right.$ and $\left.9.04 \times 10^{-3} \mathrm{mg} \mathrm{N} / \mathrm{L}\right)$ with increased values of $k_{0 Z 2}$ on 272 day $(0.248$ day $\left.^{-1}\right)$ and by 266 th day $\left(0.213\right.$ day $\left.^{-1}\right)$. In the coastal Regions 1 and 3, the first maximum of the $Z 2 \mathrm{~N}$ biomass is formed respectively on the $221 \mathrm{st}$ and 257 th days $\left(4.23 \times 10^{-3}\right.$ and $\left.2.91 \times 10^{-3} \mathrm{mg} \mathrm{N} / \mathrm{L}\right)$, and the increased values of $k_{0 Z 2}$ are fixed in the specified areas by 209th day $\left(0.242\right.$ day $\left.^{-1}\right)$ and on the 250th day $\left(0.162\right.$ day $\left.^{-1}\right)$. The second broad maximum of Z2N occurs in Regions 1 and 3, respectively, at 267-293rd days (4.33-5.17) $\times 10^{-3} \mathrm{mg}$ $\mathrm{N} / \mathrm{L}$ and at $281-293 \mathrm{rd}$ days $(3.96-4.18) \times 10^{-3} \mathrm{mg} \mathrm{N} / \mathrm{L}$ at elevated $k_{0 Z 2}$ values, fixed in the specified Regions on the 274th day $\left(0.223\right.$ day $\left.^{-1}\right)$ and on the 286th day $\left(0.191\right.$ day $^{-1)}$ (Fig. 5 d).

The formation of $Z 2 \mathrm{~N}$ production in the waters of Regions 1 and 3 occurs in JulyNovember and July-December, respectively, and in Regions 2 and 4 - in June-November. The limits of changes in the values of $\mathrm{BP}_{Z 2 \mathrm{~N}}$ for Regions $1-4$ are $0.0051-0.0267,0.0003-$ $0.0881,0.0006-0.0218$, and $0.0008-0.0867, \mathrm{~g} \mathrm{~N} /\left(\mathrm{m}^{3} \times\right.$ month) respectively for the total values of $0.0897,0.2855,0.0634$, and 0.2687 thousand tons $\mathrm{N}$. At the expression of $Z 2 \mathrm{~N}$ production on the volume of the upper layer water, the ranges of values of $\mathrm{BP}_{Z 2 \mathrm{~N}}$ for Regions $1-4$ are $7.8-76.8,0.1-61.1,1.9-45.8$, and $0.3-73.0$ thousand tons N/month with the total values for the entire production period respectively $216.4,201.0,119.2$, and 228.9 thousand tons $\mathrm{N}$.

The highest values of $\mathrm{BP}_{Z 2 \mathrm{~N}}$ in the waters of coastal Regions 1 and 3 occur in October ( 0.0267 and $0.0218 \mathrm{~g} \mathrm{~N} /\left(\mathrm{m}^{3} \times\right.$ month) respectively, or 76.8 and 45.8 thousand tons $\mathrm{N} /$ month), and in Regions 2 and 4 offshore - in August, with the expression of $\mathrm{BP}_{Z 2 \mathrm{~N}}$ per unit volume of the upper layer water $\left(0.0881\right.$ and $\left.0.0867 \mathrm{~g} \mathrm{~N} /\left(\mathrm{m}^{3} \times \mathrm{month}\right)\right)$, or in the expression of $\mathrm{BP}_{Z 2 \mathrm{~N}}$ for the whole volume of the upper layer water in September $(61.1$ and 65.1 thousand tons $\mathrm{N} / \mathrm{month}$ ).

\section{Conclusions}

Intra-annual dynamics of the BS concentrations was reproduced in Regions 1-4 (NESS) using the CNPSi-model and the long-term measurements with the monthly mean values of the sea water state parameters (temperature, light intensity, transparency, biogen load, water exchange parameters between Regions 1-4 and open water areas of the Sea of Okhotsk). The parameters of water exchange between regions and the rates of vertical 
water exchange between the upper and lower layers were calculated with the help of $\mathrm{BOM}$ on the basis of long-term values of the thermohaline parameters of the marine environment averaged for each month. The mean morphometric characteristics of Regions 1-4 of NESS were also used in calculations. The subdivision of the water column into the upper and lower layers was determined during the cold months by the depth of penetration of the winter vertical circulation (100-150 m), and in the warm season - by the warming up of the water column varying from 10-20 $\mathrm{m}$ in May to 40-50 $\mathrm{m}$ in September.

Calculations showed that the Tym' River annual runoff provides the input of relatively small amount of BS in the marine environment of Region 3: DOC - 5.97 thous. tons of $\mathrm{C}, \mathrm{DON}-0.12, \mathrm{NH}_{4}-<0.01, \mathrm{NO}_{2}-<0.01, \mathrm{NO}_{3}-0.08, \mathrm{ND}-0.30$ thousand tons of N, DIP and DOP - to 0.02, PD - 0.09 thousand tons of P, DISi - 2.38 thousand tons of Si. During a year, the intensity of BS outflow by the river runoff into the sea waters of Region 3 varies: in May-June, it is $\sim 50-79.5 \%$ of annual BS discharges, in winter months it decreases to $<10 \%$, and in summer and the autumn months - amounts to $\sim 15-$ $25 \%$ of the annual river flow.

Bilateral water exchange between regions 1-4 differently forms the nutrient load of each region: in Region 1, the loss of BS for output by the counterflow is substantially lower than their input at the water exchange with neighboring areas; in Regions 2 and 4, the BS input is less than their removal to neighboring areas; in Region 3, the input of BS is higher for some coumpounds (for DOC, $\mathrm{ND}, \mathrm{PD}, \mathrm{NH}_{4}, \mathrm{NO}_{2}$ and DIP). During a year, the input of $\mathrm{BS}$ into the marine environment with atmospheric moisture was the lowest in February (3.6 and 5.0\% in relation to annual assessment for Regions 1-2 and 3-4, respectively) and the largest in September (14.1 and 11.5\% for these regions).

The main BS input into the marine environment provides an internal recycle and turnover of BS which plays an important role in maintaining the vital activity of organisms and in the development of biohydrochemical processes in the marine environment.

Analysis of modeling results showed significan seasonal differences in the values of BS concentrations, their amplitudes and ratios in waters of Regions 1-4 in this section of the Sakhalin Shelf. In general, in waters of Regions 1-4, smaller changes in the ratios of the suspended components $\mathrm{N}$ and $\mathrm{P}$ were revealed in comparison with the dissolved and total concentrations of these elements. This is special feature of the sea waters in Region 3 which are influenced by the runoff of Tym' River. It should also be noted that in coastal Regions 1 and 3, the ranges of variability of the ratios of dissolved and total concentrations of $\mathrm{N}$ and $\mathrm{P}$ are higher than in the waters of Regions 2 and 4 located far from the coast.

The calculated values of biomasses, specific rates of their growth and bioproductions are used for a general characterization of the conditions for the development of organism biomasses in the Regions 1-4. Until the middle of May, biomasses of heterotrophic bacteria $B 1 \mathrm{~N}$, phytoplanktons $(F 1 \mathrm{~N}, F 2 \mathrm{~N}$, and $F 3 \mathrm{~N})$, and zooplanktons (herbivorous $Z 1 \mathrm{~N}$, and predatory $Z 2 \mathrm{~N}$ ) remain low in this area of the Sakhalin Shelf, and the main biomass changes occur from mid-May to late-December. These changes differ in coastal waters (in Regions 1 and 3) and in waters of Regions 2 and 4 (located far from the coast). 
During a year in the considered development of organism, two seasonal maxima (in spring, and in autumn) were shown for biomasses of $B 1 \mathrm{~N}, F 1 \mathrm{~N}$, and $Z 1 \mathrm{~N}$. In coastal Regions 1 and 3, between the spring and autumn peaks of organism biomasses, their minimal values are marked. During a year, three-four peaks of the phytoplankton biomasses ( $F 2 \mathrm{~N}$ and $F 3 \mathrm{~N})$ are formed, as well as one maximum of $Z 2 \mathrm{~N}$ biomass. In the coastal Regions 1 and 3, they are decreased in comparison with Regions 2 and 4. Biomasses of phytoplankton $F 1 \mathrm{~N}$ and $F 2 \mathrm{~N}$ are comparable in terms of the formation dates and their values, and the biomass of phytoplankton $F 3 \mathrm{~N}$ is created later and its values is lower. In Regions 2 and 4, the biomasses of phytoplankton $F 2 \mathrm{~N}$ and $F 3 \mathrm{~N}$ peaks are formed earlier in time than in coastal Regions 1 and 3. The values of successively formed peaks of the $F 3 \mathrm{~N}$ biomasses in Regions 1 and 3 are increased, and in Regions 2 and 4 they are decreased. As a whole in all regions, the each next $F 3 \mathrm{~N}$ biomass minimum between their maximal values are higher than their previous minimal values.

In Region 1, the development of biomass of heterotrophic bacteria $B 1 \mathrm{~N}$ in spring and autumn is characterized by the values $k_{0 B 1} 0.186$ and 0.092 day $^{-1}$ respectively, and in Region $3-0.297$ and 0.178 day $^{-1}$. In Regions 2 and 4, the formation of the spring peak of $B 1 \mathrm{~N}$ biomass is characterized by the values of $k_{0 B 1} 0.050-0.056$ day $^{-1}$. The autumn peak of $B 1 \mathrm{~N}$ biomass is not expressed here.

Biomass of phytoplankton $F 1 \mathrm{~N}$ is formed in spring with the largest values of $k_{0 F 1}$ in Regions 1 and $3-0.385$ and 0.166 day $^{-1}$, and in autumn -0.319 and 0.156 day $^{-1}$, respectively. In Regions 2 and 4, the largest values of $k_{0 F 1}$ for the development of the $F 1 \mathrm{~N}$ biomass were lower - 0.127-0.125 day ${ }^{-1}$ (in spring) and $0.100-0.091$ day $^{-1}$ (in autumn).

The alternating four maxima of $F 2 \mathrm{~N}$ biomass were formed more rapidly and simultaneously in remoted from the coast regions, and they were characterized in Regions 2 and 4 by the following values of $k_{0 F 2}-$ on the 178-183-rd days: $0.498-0.524$ and $0.533-$ 0.540 day $^{-1}$; on the 238th day: 0.300 and 0.230 day $^{-1}$; on the 276th day: 0.278 and 0.230 day $^{-1}$; on the 306th day: 0.383 and 0.430 day $^{-1}$. A week later, the same $F 2 \mathrm{~N}$ maxima were formed in the coastal regions, and their formation occurred at the following elevated values of $k_{0 F 2}$ in Regions 1 and 3: on the 191st day: 0.431 and 0.520 day $^{-1}$; on the 238th day: 0.389 and 0.330 day $^{-1}$; on the 278th day: 0.377 and 0.416 day $^{-1}$; and on the 308 day: 0.322 and 0.383 day $^{-1}$.

The formation of alternating three maxima of $F 3 \mathrm{~N}$ biomass is also faster in Regions 2 and 4. The following increased values of $k_{0 F 3}$ were observed respectively in Regions 2 and 4: 0.277 and 0.213 day $^{-1}$ (on 201st day); 0.436 and 0.383 day $^{-1}$ (on 238th days); 0.347 and 0.303 day $^{-1}$ (on 279th day). The formation of F3N maxima in the coastal regions occurs with a delay of two weeks, while in the Regions 1 and 3 the following increased values of $k_{0 \mathrm{~F} 3}$ were recorded: 0.148 and 0.141 day $^{-1}$ (on the 214 th days), 0.265 and 0.233 day $^{-1}$ (on the 238th day), 0.275 and 0.280 day $^{-1}$ (on the 279th day).

The spring peak of the $Z 1 \mathrm{~N}$ biomass is also formed earlier in the regions remote from the coast. They are characterized by elevated values of $k_{0 Z 1}$ in Regions 2 and 4 (respectively 0.551 and $0.528 \mathrm{day}^{-1}$ on the 173rd day). In coastal Regions 1 and 3, the largest values of $k_{0 Z 1}$ for the spring maximum of $Z 1 \mathrm{~N}$ biomass were fixed on the 185th 
day (0.605 and 0.411 day $^{-1}$ respectively). In Regions $1-4$ for the autumn peak of $Z 2 \mathrm{~N}$ biomass, the largest values of $k_{0 Z 1}$ were $0.325,0.332,0.319$, and 0.300 day $^{-1}$, respectively, and these largest values of $k_{0 Z 1}$ were noted in the 298th day.

The first maximum of the Z2N biomass is formed earlier in the Regions 2 and 4 remote from the coast, and they are characterized by elevated values of $k_{0 Z 2}(0.179$ and 0.118 day $^{-1}$, respectively, at the 197 th day). In the coastal regions, the first maximum of Z2N is formed almost two weeks later, and in Regions 1 and 3, they are characterized by the largest values of $k_{0 Z 2}\left(0.242\right.$ and 0.162 day $^{-1}$, respectively, recorded on the 209th and 250th days). The second maximum of the $\mathrm{Z} 2 \mathrm{~N}$ biomass in the waters of Regions $1-4$ is characterized by the corresponding largest values of $k_{0 Z 2} 0.223,0.248,0.191$, and 0.213 day $^{-1}$ (they were noted in the indicated regions respectively on the $274 \mathrm{th}, 272 \mathrm{nd}$, 286th, and 266th days).

The values of the organism production, $\mathrm{BP}_{\mathrm{i}}$, are positive in the second half of a year. These values characterize the conditions for the development of organism biomassses, and values of $\mathrm{BP}_{\mathrm{i}}$ are calculated in two dimensions for each region on the basis of the sum of the substance fluxes that form the biomass of the considered group of organisms at each step in time: 1. per unit volume of water in the layer under consideration for each month ( $\mathrm{g}$ of Element $/\left(\mathrm{m}^{3} \times\right.$ month $)$ ) and 2 . for the whole water volume of the layer considered (in thousand tons of Element / month). The analysis of biomass development indices showed that each group of organisms are characterized by the values of their activity indicators for a particular period of a year.

\section{Acknowledgments}

This research was performed in the framework of state assignment - theme No. 0149-2018-0015 (Shirshov Institute of Oceanology, RAS) and theme No. 5.9510.2017/8.9 (Sakhalin State University, Russia).

\section{References}

Berntsen J. USERS GUIDE for a modesplit s-coordinate numerical ocean model. Bergen: Univ. of Bergen, 2004, p. 51.

Leonov A.V. Modelirovanie prirodnyh processov na osnove imitacionnoj gidroekologicheskoj modeli transformacii soedinenij C, N, P, Si: uchebnoe posobie (Modeling of Natural Processes on the Base of Simulation Hydroecological Model of the C, N, P, Si Substance Transformations. Manual Handbook), Uzhno-Sakhalinsk: Sakhalinsk State University, 2012, (In Russian).

Leonov A.V. and Pishchal'nik V.M. Biotransformations of Organogenic Substances in the Aniva Bay Waters: Assessment with the Use of Mathematical Modeling. Water Resources, 2005a, Vol. 32, No. 5, pp. 508-523, (Original Russian Paper: Leonov A.V., Pishchal'nik V.M. Biotransformaciya organorennyh veshchestv v vodah zaliva Aniva: ocenka c pomosh'u matematicheskogo modelirovaniya. Vodnye Resursy, 2005a, Vol. 32, No. 5, pp. 558-574).

Leonov A.V. and Pishchal'nik V.M. Analysis of Conditions of Petroleum Hydrocarbon Transformations in Seawater and Simulation of This Process in Aniva Bay. Water Resources., 2005b, Vol. 32, No. 6, pp. 653-666, (Original Russian Paper: Leonov A.V., 
Pishchal'nik V.M. Biotransformaciya of neftianyh uglevodorodov v vodah zaliva Aniva: ocenka c pomosh'u matematicheskogo modelirovaniya. Vodnye Resursy, 2005b, Vol. 32, No. 6, pp. 712-726.

Leonov A.V., Pishchal'nik V.M., and Zaripov O.M. Modelirovanie prirodnyh processov: sistema otobrazheniya resul'tatov raschetov on CNPSi-vodeli: Uchebnoe posobie. (Modeling of Natural Processes: System for the Visualization of Calculation Results of Obtained by the CNPSi-model. Manual Handbook), Uzhno-Sakhalinsk: Sakhalinsk State University, 2012, (In Russian).

Leonov A.V., Pishchal'nik V.M., and Chicherina O.V. Transformations of Biogenic Substances in Tatar Strait Water (the Sea of Japan): Analysis of Mathematical Modeling Results. Water Resources, 2010 a, Vol. 37, No. 1, pp. 33-57, (Original Russian Paper: Leonov A.V. et al. Transformaciya biogennyh veshchestv v vodah Tatarskogo proliva (Japonskoe more): analiz resul'tatov matematicheskogo modelirovaniya. Vodnye Resursy, 2010 a, Vol. 37, No. 1, pp. 35-59).

Leonov A.V., Pishchal'nik V.M., and Chicherina O.V. Modeling of the Marine Environmental Pollution by Petroleum Hydrocarbons and Their Biotransformation in Tatar Strait Waters. Water Resources, 2010 b, Vol. 37, No. 2, pp. 220-233. (Original Russian Paper: Leonov A.V. et al. Transformaciya zagriasneniya morskoj sredy neftianymi uglevodorodami i ih biotransformaciya v vodah Tatarskogo proliva. Vodnye Resursy, 2010 b, Vol. 37, No. 2, pp. 225-238).

Leonov A.V., Pishchal'nik V.M., and Chicherina O.V. Biogeochemistry of Marine Environment Transformations of Biogenic Substances and Oil Hydrocarbons on the Southeastern Sakhalin Shelf. Water Resources, 2016, Vol. 43, No. 2, pp. 306-327. (Original Russian Paper: Leonov A.V. et al. Biogeohimiya morskoj sredy i osobennosti transformacii biogennyh veshchestv i nephtyannyh uglevodorodov na ugo-vostochnom shelfe Sahalina. Vodnye Resursy, 2016, Vol. 43, No. 2, pp. 164-187).

Leonov A.V. and Sapozhnilov V.V. Biohydrohimicheskaya model' transformacii organogennyh veshchestv i ee ispol'zovanie dlia rascheta pervichnoj produccii v ecosisteme Ohotskogo moria (Proceedings: Biohydrochemical Model of Organic Substance Transformations and its Applying for Primary Production Calculations in the Okhotsk Sea Ecosystem). Sb.: Kompleksnye issledovaniiya ecosistemy Ohoskogo moria (Complex Studies of the Okhotsk Sea Ecosystem), Moscow: Izdat. VNIRO, 1997, pp. 143-166, (In Russian).

Luchin V.A. Neperiodicheskie techeniya. Gidrometeorologiya I gidrohimiya morej. (Aperiodical currents. Hydrometeorology and hydrochemistry of seas). SPb.: Hydrometeoizdat, 1998, Vol. 9: The Sea of Okhotsk, Is. 1: Gydrometeorological conditions, pp. 233-256, (In Russian).

Pishchal'nik V.M., Arkhipkin V.S., and Leonov A.V. Reconstruction of the Annual Variations of Thermohaline Characteristics and Water Circulation on the Northeastern Sakhalin Shelf. Water Resources, 2014, Vol. 41, No. 4, pp. 385-395. (Original Russian Paper: Pishchal'nik V.M. et al. Vosstanovlenie godovogo hoda termohalinnyh characteristic i cirkulyacii vod na severo-vostochnom shel'fe Sahalina. Vodnye Resursy, 2014, Vol. 41, No. 4, pp. 362-374).

Pishchal'nik V.M. and Bobkov A.O. Okeanograficheskii atlas shel'fovoi zony ostrova Sakhalin (Oceanographic Atlas of the Sakhalin Island Shelf Zone). Yuzhno-Sakhalinsk: Izd. SakhGU, 2000, (In Russian).

Pishchal'nik V.M. and Leonov A.V. Studying the Ecosystem Functioning Conditions in Aniva Bay - La Peruse Strait. Water Resources, 2003, Vol. 30, No. 5, pp. 569-588. (Original Russian Paper: Pishchal'nik V.M., Leonov A.V. Izuchenie uslovij funkcionirovaniya ecosistemy zaliv Aniva - proliv Laperuza. Vodnye Resursy, 2003, Vol. 30, No. 5, pp. 616-636). 
Pishchal'nik V.M., Leonov A.V., Arkhipkin V.S., and Melkij V.A. Matematicheskoe modelirovanie uslovij funkcionirovaniya ekosistemy Tatarskogo proliva (Mathematical Modeling of Conditions in the Functioning of the Tatar Strait Ecosystem), Uzhno-Sakhalinsk: SakhGU, 2011, (In Russian).

\title{
ТРАНСФОРМАЦИЯ БИОГЕННЫХ ВЕЩЕСТВ В ВОДАХ СЕВЕРО- ВОСТОЧНОЙ ЧАСТИ ШЕЛЬФА САХАЛИНА: АНАЛИЗ РЕЗУЛЬТАТОВ МАТЕМАТИЧЕСКОГО МОДЕЛИРОВАНИЯ
}

\author{
А. В. Леонов ${ }^{1}$, В. М. Пищальник ${ }^{2}$, В.И. Петухов ${ }^{3}$, О.В. Чичерина \\ ${ }^{1}$ Институт Океанологии им. П.П.Ширшова РАН \\ 117997, Москва, Нахимовский пр. 36 \\ ${ }^{2} 693008$, Южно-Сахалинск, СахГУ, ул. Ленина 290 \\ 3690091, Владивосток, ДВФУ, Ул. Суханова 8 \\ E-mail:aleonov@ocean.ru
}

Статья поступила в редакцию 01.06.2018, одобрена к печати 18.09.2018

Трансформация биогенных веществ в морской среде исследовалась в районах $1-4$ в акватории северо-восточной части шельфа Сахалина. Три электронных инструмента использовано для анализа океанографических данных:

1. ГИС «Сахалинский шельф» (для получения данных по термохалинным параметрам морских вод);

2. океаническая динамическая модель Бергенского университета (для оценки скоростей и направлений переноса водных масс через границы районов);

3. гидроэкологическая CNPSi-модель (для расчетов динамики химикобиологических характеристик и количественной оценки особенностей биогидрохимии морской среды северо-восточной части шельфа Сахалина).

В данном исследовании обсуждается сезонная динамика концентраций органических и минеральных соединений биогенных элементов ( $\mathrm{N}$ и $\mathrm{P})$ и биомасс организмов (гетеротрофные бактерии, три группы фито- и две зоопланктона). Динамика была воспроизведена на основе долгосрочных среднемесячных значений параметров морской среды (температура, освещенность, прозрачность водной среды, биогенная нагрузка, параметры водообмена). Указанные организмы вовлечены в трансформацию биогенных веществ и обеспечивают их круговорот в водной среде. Анализ изменений концентраций биогенных веществ позволил характеризовать сезонные условия развития биомасс и изменения параметров их активности (на основе оценки удельных скоростей роста биомасс и биопродукции).

Ключевые слова: модели для анализа океанологических данных; концентрации биогенных веществ; биомассы организмов низших трофических звеньев гетеротрофные бактерии, три доминирующих группы фитопланктона, две группы зоопланктона (растительноядный и хищный); параметры активности организмов (удельные скорости роста, круговорот биомассы, биопродукция) 


\section{Литература}

Berntsen J. USERS GUIDE for a modesplit s-coordinate numerical ocean model. Bergen: Univ. of Bergen, 2004. P. 51.

Leonov A.V. Modelirovanie prirodnyh processov na osnove imitacionnoj gidroekologicheskoj modeli transformacii soedinenij C, N, P, Si: uchebnoe posobie (Modeling of Natural Processes on the Base of Simulation Hydroecological Model of the C, N, P, Si Substance Transformations. Manual Handbook). Uzhno-Sakhalinsk: Sakhalinsk State University, 2012 (In Russian).

Leonov A.V., Pishchal'nik V.M. Biotransformations of Organogenic Substances in the Aniva Bay Waters: Assessment with the Use of Mathematical Modeling // Water Resources. 2005a. Vol. 32. No. 5. P. 508-523. (Original Russian Paper: Leonov A.V., Pishchal'nik V.M. Biotransformaciya organorennyh veshchestv v vodah zaliva Aniva: ocenka c pomosh'u matematicheskogo modelirovaniya // Vodnye Resursy. 2005a. Vol. 32. No. 5. P. 558-574).

Leonov A.V., Pishchal'nik V.M. Analysis of Conditions of Petroleum Hydrocarbon Transformations in Seawater and Simulation of This Process in Aniva Bay // Water Resources. 2005b. Vol. 32. No. 6. P. 653-666. (Original Russian Paper: Leonov A.V., Pishchal'nik V.M. Biotransformaciya of neftianyh uglevodorodov v vodah zaliva Aniva: ocenka c pomosh'u matematicheskogo modelirovaniya // Vodnye Resursy. 2005b. Vol. 32. No. 6. P. 712-726.

Leonov A.V., Pishchal'nik V.M., Zaripov O.M. Modelirovanie prirodnyh processov: sistema otobrazheniya resul'tatov raschetov on CNPSi-vodeli. Uchebnoe posobie (Modeling of Natural Processes: System for the Visualization of Calculation Results of Obtained by the CNPSi-model. Manual Handbook) // Uzhno-Sakhalinsk: Sakhalinsk State University, 2012. (In Russian).

Leonov A.V., Pishchal'nik V.M., Chicherina O.V. Transformations of Biogenic Substances in Tatar Strait Water (the Sea of Japan): Analysis of Mathematical Modeling Results // Water Resources. 2010a. Vol. 37. No. 1. P. 33-57. (Original Russian Paper: Leonov A.V. et al. Transformaciya biogennyh veshchestv $\mathrm{v}$ vodah Tatarskogo proliva (Japonskoe more): analiz resul'tatov matematicheskogo modelirovaniya // Vodnye Resursy. 2010a. Vol. 37. No. 1. P. 35-59).

Leonov A.V., Pishchal'nik V.M., Chicherina O.V. Modeling of the Marine Environmental Pollution by Petroleum Hydrocarbons and Their Biotransformation in Tatar Strait Waters // Water Resources. 2010b. Vol. 37. No. 2. P. 220-233. (Original Russian Paper: Leonov A.V. et al. Transformaciya zagriasneniya morskoj sredy neftianymi uglevodorodami i ih biotransformaciya v vodah Tatarskogo proliva// Vodnye Resursy. 2010 b. Vol. 37. No. 2. P. 225-238).

Leonov A.V., Pishchal'nik V.M., Chicherina O.V. Biogeochemistry of Marine Environment Transformations of Biogenic Substances and Oil Hydrocarbons on the Southeastern Sakhalin Shelf // Water Resources. 2016. Vol. 43. No. 2. P. 306-327. (Original Russian Paper: Leonov A.V. et al. Biogeohimiya morskoj sredy i osobennosti transformacii biogennyh veshchestv i nephtyannyh uglevodorodov na ugo-vostochnom shelfe Sahalina // Vodnye Resursy. 2016. Vol. 43. No. 2. P. 164-187).

Leonov A.V., Sapozhnilov V.V. Biohydrohimicheskaya model' transformacii organogennyh veshchestv i ee ispol'zovanie dlia rascheta pervichnoj produccii v ecosisteme Ohotskogo moria (Biohydrochemical Model of Organic Substance Transformations and its Applying for Primary Production Calculations in the Okhotsk Sea Ecosystem) // Sb. Kompleksnye issledovaniiya ecosistemy Ohoskogo moria (Complex Studies of the Okhotsk Sea Ecosystem) M.: Izdat. VNIRO, 1997. P. 143-166. (In Russian). 
Luchin V.A. Neperiodicheskie techeniya // Gidrometeorologiya I gidrohimiya morej. (Aperiodical currents. Hydrometeorology and hydrochemistry of seas) // SPb.: Hydrometeoizdat, 1998. Vol. 9: The Sea of Okhotsk, Is. 1: Gydrometeorological conditions. P. 233-256. (In Russian).

Pishchal'nik V.M., Arkhipkin V.S., Leonov A.V. Reconstruction of the Annual Variations of Thermohaline Characteristics and Water Circulation on the Northeastern Sakhalin Shelf // Water Resources. 2014. Vol. 41. No. 4. P. 385-395. (Original Russian Paper: Pishchal'nik V.M. et al. Vosstanovlenie godovogo hoda termohalinnyh characteristic i cirkulyacii vod na severo-vostochnom shel'fe Sahalina // Vodnye Resursy. 2014. Vol. 41. No. 4. P. 362-374).

Pishchal'nik V.M., Bobkov A.O. Okeanograficheskii atlas shel'fovoi zony ostrova Sakhalin (Oceanographic Atlas of the Sakhalin Island Shelf Zone), Yuzhno-Sakhalinsk: Izd. SakhGU, 2000. (In Russian).

Pishchal'nik V.M., Leonov A.V. Studying the Ecosystem Functioning Conditions in Aniva Bay La Peruse Strait // Water Resources. 2003. Vol. 30. No. 5. P. 569-588. (Original Russian Paper: Pishchal'nik V.M., Leonov A.V. Izuchenie uslovij funkcionirovaniya ecosistemy zaliv Aniva - proliv Laperuza // Vodnye Resursy. 2003. Vol. 30. No. 5. P. 616-636).

Pishchal'nik V.M., Leonov A.V., Arkhipkin V.S., Melkij V.A. Matematicheskoe modelirovanie uslovij funkcionirovaniya ekosistemy Tatarskogo proliva (Mathematical Modeling of Conditions in the Functioning of the Tatar Strait Ecosystem). Uzhno-Sakhalinsk: SakhGU, 2011. (In Russian). 